Please note that this manuscript is a non-peer reviewed preprint that has been submitted for publication in Marine Pollution Bulletin on the $23^{\text {rd }}$ November 2020. Subsequent versions of this manuscript may have slightly different content. If accepted, the final version of the manuscript will be available via the "Peer-Reviewed Publication DOI" link. Please feel free to contact Marites Canto with any feedbacks. 


\section{A benthic light index of water quality in the Great Barrier Reef, Australia}

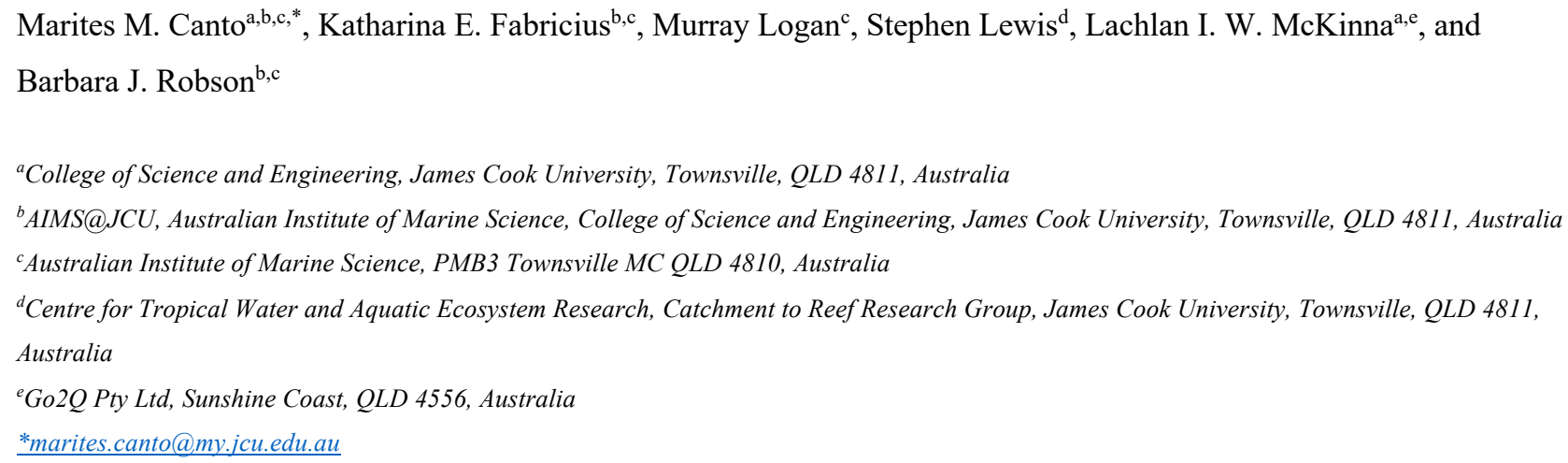

\section{Abstract}

Good water quality is essential to the health of marine ecosystems, yet current metrics used to track water quality in the Great Barrier Reef are not strongly tied to ecological outcomes. There is a need for a better water quality index (WQI). Benthic light, the amount of light reaching the seafloor, is critical for coral and seagrass health and is strongly affected by water quality. It therefore represents a strong candidate for use as a water quality indicator. Here, we introduce a new index based on remote sensing benthic light (bPAR) from ocean colour. Resulting bPAR index timeseries, based on the extent to which the observed bPAR fell short of the locally- and seasonally- specific optimum, showed strong spatial and temporal variability, which was consistent with the dynamics that govern changes in water clarity in the Great Barrier Reef. Our new index is ecologically relevant, responsive to changes in light availability and provides a robust metric that may complement current Great Barrier Reef water quality metrics.

\section{Keywords}

benthic light; benthic photosynthetically active radiation; benthic light stress; water quality; water quality index; Great Barrier Reef

\section{Introduction}

\subsection{Great Barrier Reef and water quality}

Coastal oceans around the world are vulnerable to the impacts of multiple stressors ranging from increased coastal developments and anthropogenic activities to extreme weather events and climate change. Unfortunately, the Great Barrier Reef (GBR) is not impervious to these stressors (Wolff et al., 2018). The GBR is one of the most diverse marine habitats on Earth and forms a critical part of the Australian economy (Deloitte Access Economics, 2013) and national natural and cultural heritage (Lucas et al., 1997). Recurrent and recent mass coral bleaching due to thermal stress (Hughes et al., 2017; Hughes et al., 2018), pollution from agricultural runoffs (Kroon, 2012) and the associated declining quality of the water entering the GBR lagoon (Fabricius et al., 2016), and crown-of-thorns seastar (COTS) outbreaks (Fabricius et al., 2010) present current challenges in maintaining the health of the GBR. Considering these numerous environmental pressures, it is important for management agencies to have tools that can be used to identify and monitor changes that can impact the ecosystem's health. Understanding the factors driving these changes and how the ecosystems respond to both 
short- and long-term environmental forces (Ackleson, 2003) can help focus management actions, integrate relevant management approaches and increase the anticipated success in addressing identified challenges.

One of the main priorities for maintaining the health and resilience of the GBR ecosystems is the management of water quality flowing into the Reef since poor water quality can reduce light availability at depth. Poor water quality is considered a key factor for declining marine ecosystem health (Fabricius et al., 2016) and regarded as the major threat to the health of the GBR (De'ath and Fabricius, 2010; Devlin et al., 2015). The need to address the threats associated with declining quality of the water (Fabricius et al., 2016) was greatly recognised by both the Australian and Queensland Governments' and reflected on the implementation of the Reef 2050 Long-term Sustainability Plan (Reef 2050 Plan) (Commonwealth of Australia, 2015). The Reef 2050 Plan aims to preserve the heritage value of the Reef between now and 2050 and to provide support to the development and implementation of water quality improvement plans strategic to relevant catchment and coastal systems along the length of the GBR, including development of tools to inform and monitor GBR water quality.

\subsection{The ecological importance of benthic light}

Light is essential for photosynthesis, the foundation of all food webs and the dominant source of energy for corals and seagrasses (Kirk, 2011). For these benthic organisms, the most important part of the light spectrum is the photosynthetically active radiation (PAR) - the amount of available solar irradiance (light) typically within the 400 to $700 \mathrm{~nm}$ wavelength range - and specifically, the amount of PAR reaching the sea floor or reef surfaces, known as 'benthic PAR' (bPAR, mol photons $\mathrm{m}^{-2} \mathrm{~d}^{-1}$ ) (Magno-Canto et al., 2019; Magno-Canto et al., 2020). The spatial and temporal variability of bPAR in shallow coastal environments is a crucial control of benthic primary production and its contribution to the total primary production (Gattuso et al., 2006). It is therefore key to understanding and monitoring the dynamics and health of important benthic habitats near the coasts.

Although some species of seagrass and corals can tolerate a wide range of benthic irradiance levels, they do have light optima, and both low and high benthic light can create stress (Bessell-Browne et al., 2017; Gattuso et al., 2006; Muir et al., 2015). Some species can tolerate short periods of reduced light intensities in shallow waters, but their photosynthesis and growth may be reduced during these periods. Some seagrass taxa are able to persist to appreciable water depths owing to effective morphological and physiological adaptations to low-light conditions (Dennison, 1987; Ralph et al., 2007). However, reduced light availability, whether chronic or acute, is a threat to seagrass meadow health (Collier and Waycott, 2009; McKenzie et al., 2012), a major driver of seagrass loss in coastal and inshore GBR (Collier et al., 2012a; Collier et al., 2012b), and can strongly alter coral communities (Bessell-Browne et al., 2017; Muir et al., 2015).

Interactions between benthic irradiance and other stressors are also important for both corals and seagrasses. For example, turbidity-induced light reductions can result in reduced coral recruitment and diversity (Fabricius, 2005). Similarly, prolonged exposure to 'dark' (low to no light) conditions during high turbidity (e.g., near dredging locations) can cause sub-lethal bleaching in some corals (Bessell-Browne et al., 2017a; Bessell-Browne et al., 2017b) while others were able to adjust to combination of low light levels $\left(2.3 \mathrm{~mol}\right.$ photons $\left.\mathrm{m}^{-2} \mathrm{~d}^{-1}\right)$ and elevated suspended sediment concentrations (Jones et al., 2020). Other examples include increased coral bleaching during high irradiance in the presence of thermal stress (Leahy et al., 2013) and compromised seagrass survival during limited light levels and high nutrient conditions (McKenzie et al., 2010). Further, for some seagrass species (i.e., Halophila ovalis), additional shading in an alreadyturbid low light environment can result in complete mortality, demonstrating that historical light exposure is important in maintaining the resilience and ability of seagrasses to acclimate to chronic low light regimes (Yaakub et al., 2014). Yet, 
there is also recent evidence that during heat-induced bleaching events some turbidity can benefit nearshore reef corals by alleviating the harmful effects of the combination of thermal stress and high irradiance (Cacciapaglia and van Woesik, 2016; Fisher et al., 2019; Morgan et al., 2017; Sully and van Woesik, 2020). These results highlight the complex role of light availability to the survival, growth and maintenance of dependent benthic organisms and hence, the need to develop a water quality metric that is not only ecologically relevant but also responsive to changes in light availability.

\subsection{Physical controls of benthic PAR}

bPAR is controlled by both water quality and water column depth (Magno-Canto et al., 2019). In shallow coastal waters, bPAR is mainly determined by the attenuation of light as it travels through the water column by optically active constituents including phytoplankton, suspended non-algal particulate matter, and coloured dissolved organic matter (CDOM) which attenuate (either by absorption and/or scattering) and change the character of light with depth (Brando et al., 2012; Kirk, 2011).

Water clarity in the GBR, a parameter related to water quality and commonly expressed as Secchi depth $\left(Z_{\mathrm{sd}}\right)$ or photic depth, is affected by river discharge. River flood plumes often transport high loads of fine sediments, nutrients - that can induce phytoplankton blooms - and dissolved organic matter that directly impact coastal water clarity. Previous studies indicate that tracking interannual variability is important to understand temporal variability and to develop predictive casual relationships (Fabricius et al., 2013; Fabricius et al., 2014; Fabricius et al., 2016). Metrics to calculate the exposure of GBR reef and seagrass habitats to flood plumes have been developed (Devlin et al., 2012; Devlin et al., 2015; Petus et al., 2014) using the 'colour' of water in the vicinity of the plume from enhanced True Color satellite-imagery. These metrics have provided an integration of multiple potential impacts of flood plumes, from reduced water clarity to freshwater exposure to the potential impacts of pesticide exposure and sedimentation. As such, these exposure metrics have offered a useful estimate of risk associated with water quality that can inform targeted management of relevant catchments (Alvarez-Romero et al., 2013; Petus et al., 2018).

However, light penetration and photic depth indeed vary across the whole GBR in response to inter-annual variations in river discharge (Fabricius et al., 2014; Fabricius et al., 2016; Logan et al., 2013) which occur not only in the coastal areas adjacent to river mouths, but also in the mid- and outer-shelf areas of some regions. These effects were also not only shown to be spatially extensive but can be observed more than six months after flood plumes have dispersed, suggesting that flood plume detection is not in itself sufficient to characterise the likely spatial and temporal extent of the ecological impacts of river runoff and human activities in Queensland catchments and coastal regions.

\subsection{The need for an improved water quality index (WQI)}

A motivation for developing a benthic light-based index of water quality is the need to relate changes in bPAR to ecological outcomes such that interannual progress and variations in water quality can be tracked within the whole GBR region (i.e., within each Natural Resource Management (NRM) region and water body across the GBR shelf, see Figure 1). A WQI is a quantitative metric that provides a standardised measure of water quality indicators (examples discussed below) as compared against a threshold value (Robillot et al., 2018), defined at a level intended to help identify the need for management actions (Great Barrier Marine Park Authority, 2010b). In the GBR, the WQI is used to generate scores for water quality which forms part of the annual GBR "Report Card" (Robillot et al., 2018) used to monitor the condition and trend of GBR ecosystem health and drivers to guide management based on a consistent science-based national 
strategy for managing water quality (e.g., Reef 2050 Water Quality Improvement Plan 2017-2022 (State of Queensland, 2018) as part of the Reef 2050 Long-term Sustainability Plan (Reef 2050 Plan) (Commonwealth of Australia, 2015)).

Two water quality sub-indicators are currently used to provide information about GBR inshore marine conditions and generate a WQI reported as part of the annual GBR Report Cards: chlorophyll- $a$ pigment concentration, $\mathrm{Chl} a(\mathrm{mg} / \mathrm{L})$ as a productivity sub-indicator, and Secchi depth, $\mathrm{Z}_{\mathrm{sd}}(\mathrm{m})$ as a water clarity sub-indicator (Robillot et al., 2018). Chl $a$ associated with phytoplankton biomass is a widely-used proxy for nutrient pollution in the GBR, in that annual mean concentrations above a threshold (which varies from 2.0 to $0.4 \mathrm{mg} / \mathrm{L}$ from inshore to offshore locations) are considered an indication of water quality degradation associated with eutrophication (increased nutrient inputs, e.g., from floods or river runoffs, and a subsequent increase in phytoplankton biomass) (Schaeffer et al., 2013) and light attenuation (Platt et al., 1994). The photic depth, $Z_{\text {sd }}$ which quantifies the depth of in-water visibility (Kirk, 2011), is a common proxy for water clarity (transparency) and is inversely related to turbidity (i.e., cloudiness/opacity of the water). Declining $Z_{\text {sd }}$ indicates increased turbidity and reduced light. Although indicative of changes in water quality, $Z_{\text {sd }}$ does not directly tell us what light environments are experienced by seagrasses and corals, as the relationship varies with depth in the water column and with the colour (i.e., optical properties) of the water. Hence, while the spatial and temporal variations in $Z_{\text {sd }}$ can be characterised using existing remote sensing data products developed for the GBR (Weeks et al., 2012), translating these variations to ecological outcomes such as the exposure to stress from low-light is not straightforward.

Using satellite-derived bPAR to provide an index of water quality instead of the WQI from combined $Z_{\mathrm{sd}}$ and $\mathrm{Chl} a$ indices will allow the interacting effects of complex optically active constituents that define water clarity and the spatially variable bathymetry (water depth) to be considered. This will allow, for the first time, the application of ecologicallyrelevant, GBR-specific light thresholds for corals, seagrasses and overall ecosystem health.

The objective of this work is therefore to use the new satellite-derived estimates of daily benthic irradiance or bPAR to develop an ecologically-relevant marine index of water quality to replace or complement the current combined $Z_{\text {sd }}-$ and Chla-based index. The proposed benthic light index will incorporate the benthic light regimes within the GBR at spatial scales that is required by the GBR Marine Park Authority (GBRMPA) in the preparation and issue of the annual GBR Water Quality Report Cards.

\section{Methods}

\subsection{Study site}

The GBR Marine Park lies adjacent to the Queensland coast along the north-eastern seaboard of the Australian continent. It stretches about $2300 \mathrm{~km}$ in length, occupying the continental shelf roughly between $9^{\circ} \mathrm{S}$ and $24^{\circ} \mathrm{S}$. Along its length, there are 35 main river basins with catchment areas that drain into the GBR lagoon (Furnas, 2003), and each catchment varies in its land use (Fabricius et al., 2016) and impact on the quality of the water within the lagoon. To facilitate regional comparisons consistent with recent efforts to manage and monitor the health of waters within the GBR lagoon and account for spatial differences across the shelf, we used a combination of the NRM regional GBR catchment and cross-shelf water body boundaries which respectively include (from North to South): the Cape York, Wet Tropics, Dry Tropics (Burdekin), Mackay-Whitsunday, Fitzroy, and Burnett Mary regions, and the (i) enclosed coastal, (ii) open coastal, (iii) midshelf and (iv) offshore water bodies (Great Barrier Marine Park Authority, 2010a) (see Figure 1). For clarity, combinations of the NRM regions and the water bodies are interchangeably referred to as "zones" throughout the manuscript. 


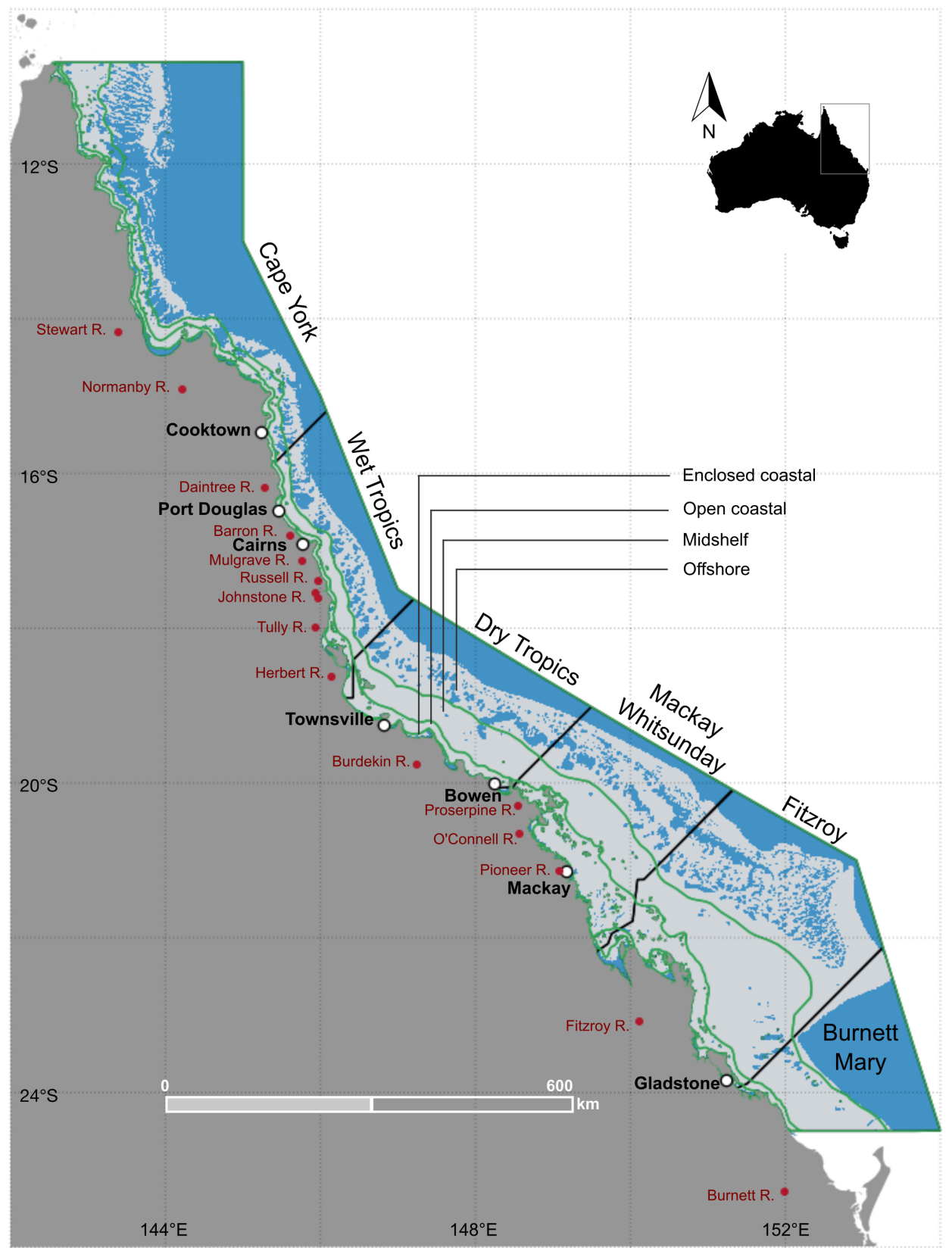

Figure 1. Map of the Great Barrier Reef showing the reef matrix, (black diagonal solid lines) boundaries of the six NRM regions (N to S: Cape York, Wet Tropics, Dry Tropics, Mackay Whitsunday, Fitzroy, and Burnett Mary) and the (green solid lines) four cross-shelf water bodies used in the analysis (Enclosed coastal, Open coastal, Midshelf and Offshore). Also indicated are several major cities (filled white circles) and rivers (filled red circles) along the length of the GBR.

Annual GBR "Report Cards" are currently used to monitor and communicate the condition and trend of GBR ecosystem health and drivers to guide management of the Reef. The GBR reporting framework uses consistent, well-defined spatial boundaries for aggregation, which are based on a combination of the NRM regions and cross-shelf water body boundaries (as shown in Figure 1) and temporal boundaries that uses a "water year" - defined as the period between 01 October to 
across reporting years (Waterhouse et al., 2017) and is hence adapted in the present study to align with the current management, monitoring and reporting framework of water quality status in the GBR.

\subsection{The bPAR index}

The development of a bPAR index requires three components: (i) a benthic light threshold relevant to targeted benthic organisms (i.e. corals and seagrasses); (ii) robust, spatiotemporally consistent estimates of bPAR data; and (ii) a method of combining these to map benthic light stress within the entire GBR and generate an index that can inform managers and policy makers of when and where benthic light conditions are less optimal for corals and seagrasses as a result of intermittent factors that control water clarity. The following sections provide more detail for each of these components.

\subsubsection{Benthic light responses and thresholds for key GBR coral and seagrass species}

Information about light responses and relevant thresholds for some key GBR coral and seagrass species was compiled from both field and laboratory/experimental data obtained from complementary laboratory studies and a review of pertinent literature. Our purpose is to determine a collective maximum benthic light threshold that both corals and seagrasses could potentially make use of for photosynthesis and growth under varying water quality conditions.

The relationship between light intensity and photosynthesis is modelled as a photosynthesis-irradiance (P-E) curve (Sakshaug, 1997) which provides a measure of the efficiency of utilization of the incident light (Kirk, 2011). In a P-E curve, photosynthetic rates initially increase linearly with irradiance until the maximum photosynthetic potential, $P_{\max }$, is reached. Further increases in irradiance then result to photosynthetic rates plateauing, until the point of light-induced reduction in photosynthetic capacity of the plant (i.e., photoinhibition) (Sakshaug, 1997). P-E curves thus provide the information needed to define a relevant threshold for our benthic light index.

Most of the previous studies that examined benthic light requirements have focused on determining the lowest light limits at which species are being found (e.g., (Gattuso et al., 2006; Muir et al., 2015). In contrast, we focused our index on the light needed to obtain $\mathrm{P}_{\max }$, as below this level, the organisms' growth rates are compromised, and above this $\mathrm{P}_{\max }$, there are no further growth benefits of increased light.

Light requirements and responses of corals and seagrasses to light vary considerably between species and conditions (Table 1). For example, Muir et al. (2015) has suggested that for Acropora corals, the most important reef-building coral species found in the GBR, a winter PAR threshold of 5.2 mol photons $\mathrm{m}^{-2} \mathrm{~d}^{-1}$ strongly determines their depth limits, a value relatively lower than the 7 to $8 \mathrm{~mol}$ photons $\mathrm{m}^{-2} \mathrm{~d}^{-1}$ light limit for reef formation reported by (Kleypas, 1997). Considering the surface area corresponding to global coastal oceans where important benthic organisms flourish, Gattuso et al. (2006) also calculated a mean benthic irradiance of 1.2 mol photons $\mathrm{m}^{-2} \mathrm{~d}^{-1}$ at the maximum depth of coral colonisation as well as a mean compensation irradiance for benthic communities at a range of 0.24 to 4.4 mol photons $\mathrm{m}^{-}$ ${ }^{2} \mathrm{~d}^{-1}$. Gattuso et al. (2006)'s mean benthic irradiance value is comparable to benthic light threshold for reef development of $\sim 2$ mol photons $\mathrm{m}^{-2} \mathrm{~d}^{-1}$ estimated for Whitsunday Islands in the GBR - a region with strong water quality gradient (Cooper et al., 2007) and in the Gulf of Siam (Titlyanov and Latypov, 1991). A benthic PAR threshold for other important benthic habitats (e.g., macroalgae) has also been reported where levels below 2 mol photons $\mathrm{m}^{-2} \mathrm{~d}^{-1}$ were found to cause steep declines in macroalgal species richness (Hurrey et al., 2013) while other assemblages such Lobophora-turf and Halimeda/Bryopsidales have strong affinity to light thresholds of 3.6 mol photons $\mathrm{m}^{-2} \mathrm{~d}^{-1}$ and 4.6 mol photons $\mathrm{m}^{-2} \mathrm{~d}^{-1}$, respectively. 
For seagrasses, average daily irradiance (i.e., PAR) above 5.0 to $8.4 \mathrm{~mol}$ photons $\mathrm{m}^{-2} \mathrm{~d}^{-1}$ has been associated with increased seagrass abundance (i.e., cover) but prolonged exposure to conditions below 3.0 mol photons $\mathrm{m}^{-2} \mathrm{~d}^{-1}$ resulted in $50 \%$ seagrass cover loss (Collier et al., 2012a). More than 4 weeks of light below 5.0 mol photons $\mathrm{m}^{-2} \mathrm{~d}^{-1}$ also resulted in a decline in seagrass condition (i.e., biomass, shoot density and percent cover) (Chartrand et al., 2016). Hence, for seagrasses, it has been suggested that risk of light limitation may occur when average daily benthic PAR falls below 5 to $6 \mathrm{~mol}$ photons $\mathrm{m}^{-2} \mathrm{~d}^{-1}$ (Chartrand et al., 2016; Collier et al., 2012a) although some deep-water species (e.g., Halophila

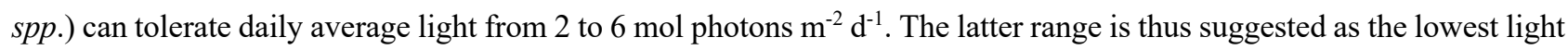
threshold for managing acute impacts of light limitation on seagrasses, while 10 to 13 mol photons $\mathrm{m}^{-2} \mathrm{~d}^{-1}$ is the currently suggested limit for managing long term chronic impacts of light limitation on seagrasses (Collier et al., 2016a).

Recent experimental studies that investigated the different responses of key GBR coral species to different water quality gradients (Strahl et al., 2019), different daily light integral (DLI) levels at either constant or variable doses (DiPerna et al., 2018), and effects of variable light on adult and juvenile corals under increasing carbon dioxide levels (Noonan et al., (in prep)) have also provided useful insights on coral light requirements relevant to the present study. For example, Strahl et al. (2019) highlighted that in a region with a strong water quality gradient (e.g., near the Burdekin River), Acropora tenuis showed reduced calcification at light levels below $\sim 10 \mathrm{~mol}$ photons $\mathrm{m}^{-2} \mathrm{~d}^{-1}$ but exhibited high growth rates (i.e., total Chl $a$ content, net photosynthesis and light and net calcification) at moderate light levels between $\sim 14$ to 16 mol photons $\mathrm{m}^{-2} \mathrm{~d}^{-1}$ (Table 1). A reduction of light by $\sim 50 \%$ (e.g., from moderate to low light levels), for instance in shallow turbid inshore waters like the Burdekin River region, markedly reduced rates of net photosynthesis and light calcification although the observed variations in water quality did not have detrimental effects on $A$. tenuis (e.g., as long as light levels received are not limiting such as when there is no light).

DiPerna et al. (2018), on the other hand, showed that coral responses to constant (high or low DLI) or variable light conditions (with alternating segments of high and low DLI levels) during a 20-day laboratory experiment did not vary greatly between two morphologically different GBR reef corals, Pachyseris speciosa and Acropora millepora. Specifically, the 'shade-tolerant' $P$. speciosa showed chronic light-limitation response at low DLI of 6 mol photons $\mathrm{m}^{-2}$ $\mathrm{d}^{-1}$ and light inhibition response at high DLI of $32 \mathrm{~mol}$ photons $\mathrm{m}^{-2} \mathrm{~d}^{-1}$, under both constant and variable light conditions (DiPerna et al., 2018). For a 'high-light tolerant' A. millepora exposed to the same light conditions, observed responses suggested chronic light-limitation under all conditions by the end of the experiment although growth observations noted (i.e., differences in nubbins' buoyant weight over time) in A. millepora also indicated that it was able to gain some advantage when exposed to constant high daily light. Relationships between incident irradiance and oxygen production (one of the parameters used to indicate photosynthetic efficiency) for $P$. speciosa and A. millepora at all light treatments (high, low and variable light levels) presented in the DiPerna et al. (2018) paper did not greatly differ between the coral species studied, suggesting that these corals have equivalent photosynthetic efficiency regardless of the level of instantaneous irradiance treatment received. In other words, the minimum or the maximum instantaneous light is probably less important than the total daily integrated light received as a predictor of the health and growth of these corals. This is further supported by the results obtained by (Noonan et al., (in prep)) in their laboratory experiments that investigated the effects of variable light levels and $\mathrm{pCO}_{2}$ (partial pressure of carbon dioxide, used in ocean acidification studies) on Acropora sp. reef corals. This work (Noonan et al., (in prep)) concluded that the rate of increase in photosynthesis (as measured by the changes in the relative electron transport rate) on mature Acropora $s p$. is directly related to the total amount of light the corals received within the range of light conditions it was subjected to, highlighting the importance of cumulative amount of light received as opposed to instantaneous irradiance levels. 
241 The above review has highlighted that light thresholds relevant to corals and seagrasses (and potentially other benthic organisms) vary widely (from $\sim 2 \mathrm{~mol}$ photons $\mathrm{m}^{-2} \mathrm{~d}^{-1}$ to $16 \mathrm{~mol}$ photons $\mathrm{m}^{-2} \mathrm{~d}^{-1}$ ) and that at irradiance values higher than these, there is very little additional benefit in terms of growth. In developing the benthic light limitation index, our intent is to use a parameter for benthic light stress that reflects reduced opportunity for photosynthesis due to low light, but does not consider stress (e.g., photoinhibition) due to excessively high bPAR that may be relevant during bleaching events (Leahy et al., 2013; Mumby et al., 2001) since our purpose is to produce an index of chronic light stress due to reduced water quality, which is not the cause of photo-oxidative stress during bleaching events.

Table 1. Benthic light thresholds and responses for some key GBR coral and seagrass species and other benthic organisms.

\begin{tabular}{|c|c|c|c|c|}
\hline $\begin{array}{l}\text { Taxonomic } \\
\text { group }\end{array}$ & Species & Conditions / Notes & Threshold / Response & Reference \\
\hline coral & $\begin{array}{l}\text { Acropora, } \\
\text { Isopora }\end{array}$ & $\begin{array}{l}\text { global in-situ coral identification } \\
\text { and depth data }\end{array}$ & $\begin{array}{l}\text { winter PAR threshold of } 5.2 \text { mol } \\
\text { photons } \mathrm{m}^{-2} \mathrm{~d}^{-1} \text { define colonisation } \\
\text { depth of Acropora }\end{array}$ & $\begin{array}{l}\text { (Muir et al., } \\
\text { 2015) }\end{array}$ \\
\hline coral & & $\begin{array}{l}\text { global limit for reef formation } \\
\text { (net } \mathrm{CaCO}_{3} \text { production) }\end{array}$ & 7 to $8 \mathrm{~mol}$ photons $\mathrm{m}^{-2} \mathrm{~d}^{-1}$ & (Kleypas, 1997) \\
\hline coral & & $\begin{array}{l}\text { in-situ total daily PAR, } \\
\text { Whitsunday Islands, depth limit } \\
\text { for reef development }\end{array}$ & $\begin{array}{l}\text { absolute minimum light threshold } \\
\sim 2 \text { mol photons } \mathrm{m}^{-2} \mathrm{~d}^{-1}\end{array}$ & $\begin{array}{l}\text { (Cooper et al., } \\
\text { 2007) }\end{array}$ \\
\hline coral & Scleractinia & $\begin{array}{l}\text { in-situ surface irradiance } \\
\text { (obtained as } 50 \% \text { of total solar } \\
\text { radiation above water surface), } \\
\text { depth limit for reef development, } \\
\text { Gulf of Siam }\end{array}$ & $\sim 2 \mathrm{~mol}$ photons $\mathrm{m}^{-2} \mathrm{~d}^{-1}$ & $\begin{array}{l}\text { (Titlyanov and } \\
\text { Latypov, 1991) }\end{array}$ \\
\hline coral & & $\begin{array}{l}\text { average benthic irradiance at the } \\
\text { maximum depth of coral } \\
\text { colonization }\end{array}$ & $1.2 \pm 1.7 \mathrm{~mol}$ photons $\mathrm{m}^{-2} \mathrm{~d}^{-1}$ & $\begin{array}{l}\text { (Gattuso et al., } \\
\text { 2006) }\end{array}$ \\
\hline macroalgae & $\begin{array}{l}\text { macroalgae (general) } \\
\text { Lobophora-turfs } \\
\text { Halimeda/Bryopsidales }\end{array}$ & $\begin{array}{l}\text { required light levels to maintain } \\
\text { species richness }\end{array}$ & $\begin{array}{l}\text { steep decline in richness at } 2 \mathrm{~mol} \\
\text { photons } \mathrm{m}^{-2} \mathrm{~d}^{-1} \\
3.6 \mathrm{~mol} \text { photons } \mathrm{m}^{-2} \mathrm{~d}^{-1} \\
4.6 \mathrm{~mol} \text { photons } \mathrm{m}^{-2} \mathrm{~d}^{-1}\end{array}$ & $\begin{array}{l}\text { (Hurrey et al., } \\
\text { 2013; Pitcher et } \\
\text { al., 2007) }\end{array}$ \\
\hline $\begin{array}{l}\text { benthic } \\
\text { community }\end{array}$ & & $\begin{array}{l}\text { daily compensation irradiance of } \\
\text { benthic communities }\end{array}$ & $\begin{array}{l}\text { ranges from } 0.24 \text { to } 4.4 \mathrm{~mol} \\
\text { photons } \\
\mathrm{m}^{-2} \mathrm{~d}^{-1}\end{array}$ & $\begin{array}{l}\text { (Gattuso et al., } \\
\text { 2006) }\end{array}$ \\
\hline $\begin{array}{l}\text { seagrass } \\
\text { (meadow) }\end{array}$ & $\begin{array}{l}\text { Predominantly } \\
\text { Halodule uninervis, } \\
\text { some Cymodocea } \\
\text { serrulata and } \\
\text { Halophila ovalis }\end{array}$ & $\begin{array}{l}\text { in-situ monitoring in Northern } \\
\text { GBR (sites: Magnetic Island, } \\
\text { Dunk Island and Green Island), } \\
\text { seagrass cover measure } ~ 3 \text {-month } \\
\text { intervals ( } 2008-2011) \text {, nearshore } \\
\text { reef habitats exposed } \\
\text { to influence from terrigenous } \\
\text { run-offs }\end{array}$ & $\begin{array}{l}\text { increased seagrass abundance (i.e., } \\
\text { cover) at mean daily irradiance } \\
\text { above } 5 \\
\text { and } 8.4 \text { mol photons } \mathrm{m}^{-2} \mathrm{~d}^{-1}, 16 \text { to } \\
18 \% \text { of days below } 3 \text { mol photons } \\
\mathrm{m}^{-2} \mathrm{~d}^{-1} \text { associated with } 50 \% \\
\text { seagrass cover loss }\end{array}$ & $\begin{array}{l}\text { (Collier et al., } \\
\text { 2012a) }\end{array}$ \\
\hline seagrass & $\begin{array}{l}\text { Zostera muelleri sp. } \\
\text { capricorni }\end{array}$ & $\begin{array}{l}\text { in-situ, intertidal mudbank, } \\
\text { sheltered embayment, } \\
\text { Gladstone Harbour, simulated } \\
\text { dredging impacts }\end{array}$ & $\begin{array}{l}\text { declined seagrass conditions } \\
\text { (biomass, shoot density and } \\
\text { percent cover) at } \leq 5 \mathrm{~mol} \\
\text { photons } \mathrm{m}^{-2} \mathrm{~d}^{-1} \text { for periods } \\
>4 \text { weeks, } 6 \text { mol photons } \mathrm{m}^{-2} \mathrm{~d}^{-1} \\
\text { (suggested management light } \\
\text { threshold) mitigated dredging } \\
\text { impacts }\end{array}$ & $\begin{array}{l}\text { (Chartrand et al., } \\
\text { 2016) }\end{array}$ \\
\hline
\end{tabular}


seagrass

seagrass

seagrass

seagrass

coral

coral

Pachyseris speciosa

coral

Pachyseris speciosa

aboratory experiment, constant light treatments

coral

Acropora millepora

coral
Cymodocea serrulata Halodule uninervis, Halophila ovalis and Zostera muelleri

aquaria-based experiments, six

light treatments: $0,5,10,20,40$

and $70 \%$ of surface irradiance $(=$

32.8 mol photons $\mathrm{m}^{-2} \mathrm{~d}^{-1}$ )

equivalent to light levels ranging

from 0 to $23 \mathrm{~mol} \mathrm{~m}^{-2} \mathrm{~d}^{-1}$, warm

$\left(\sim 23^{\circ} \mathrm{C}\right)$ and $\operatorname{cool}\left(\sim 28^{\circ} \mathrm{C}\right)$

temperatures over 14 weeks muelleri, Halodule uninervis, Cymodor
sp., Syringodium

isoetifolium,

Thalassodendron

hemprichii, Enhalus

acoroides

synthesis of light thresholds and guidelines for seagrass of the GBR
Halophila sp., Zostera

ciliatum, Thalassia

Halodule uninervis

Halophila ovalis and

Zostera muelleri

Acropora tenuis

laboratory experiment, variable light treatments treatments)

Acropora millepora laboratory experiment,
Cymodocea serrulata, aquaria-based experiments

field conditions, three daily light light calcification rates, and net integral (DLI) treatments (no light: 0 mol photons $\mathrm{m}^{-2} \mathrm{~d}^{-1}$, low: $7.92-9.36 \mathrm{~mol}$ photons $\mathrm{m}^{-2} \mathrm{~d}^{-1}$ and moderate: $13.86-16.38 \mathrm{~mol} \mathrm{~m} \mathrm{~m}^{-2} \mathrm{~d}^{-1}$ )

photons $\mathrm{m}^{-2} \mathrm{~d}^{-1}$ ), strong water quality gradient (Burdekin region), moderate water quality conditions (Magnetic Island), $\sim 60$ $\mathrm{km}$ from Burdekin River mouth laboratory experiment, variable light treatments (alternating high and low light treatments) (alternating high and low light constant light treatments

biological light thresholds of

2-6 mol photons $\mathrm{m}^{-2} \mathrm{~d}^{-1}$ for

managing acute impacts;

10-13 mol photons $\mathrm{m}^{-2} \mathrm{~d}^{-1}$ for

managing long term impacts of

light limitation (except for some

less light)

;

overall median of the minimum $\mathrm{m}^{-2} \mathrm{~d}^{-1}$

suggested conservative provide $50 \%$ and $80 \%$ protection period, respectively.

calcification rates from low DLI

(8-9.4 mol photons $\mathrm{m}^{-2} \mathrm{~d}^{-1}$ ) to

physiological stress in both high

and low light segments, rapid

declines in maximum quantum

yield (i.e. photoinhibition) at 32

mol photons $\mathrm{m}^{-2} \mathrm{~d}^{-1}$, recovery

(photoacclimation) within 3-5

days at $6 \mathrm{~mol}$ photons $\mathrm{m}^{-2} \mathrm{~d}^{-1}$

low values of $\mathrm{Q}_{\mathrm{m}}$ (or excitation pressures on PSII (an

estimate of light limitation against photoinhibition); chronic

light-limitation at constant low

light $\left(6 \mathrm{~mol}_{\text {photons }} \mathrm{m}^{-2} \mathrm{~d}^{-1}\right)$;

photoinhibition at constant high

light (at $32 \mathrm{~mol}$

intermediate growth in variable

daily light conditions, slow $(>20$

days) photoacclimation

reduced growth (i.e., buoyant

weight) due to photolimitation at declined seagrass shoot density

and leaf growth rates at lowest

(Collier et al.,

light levels but were maintained at

highest light levels, quicker

decline of shoot density and leaf

growth rates at low light

treatments in warm than cool

temperatures

deep water species which require

(Collier et al.,

2016a)

2016b)

global synthesis of published light minimum light requirement: range (Gattuso et al., of 0.06 to $14.1 \mathrm{~mol}$ photons $\left.\mathrm{m}^{-2} \mathrm{~d}^{-} 2006\right)$

light requirement: $5.1 \mathrm{~mol}$ photons

(Collier et al.,

management guideline thresholds 2016b)

of 7 and 13 mol photons $\mathrm{m}^{-2} \mathrm{~d}^{-1}$ to of seagrass shoots over a 14 -week

moderate light (14-16 mol photons

(DiPerna et al.,

photons $\mathrm{m}^{-2} \mathrm{~d}^{-1}$ )

(DiPerna et al., 2018)

\section{9)}

(DiPerna et al. 2018)

constant low daily light (6 mol photons $\mathrm{m}^{-2} \mathrm{~d}^{-1}$ ) compared with
(DiPerna et al., 2018) 
constant high daily light (32 mol

photons $\mathrm{m}^{-2} \mathrm{~d}^{-1}$ )

coral Acropora tenuis or A. hyacinthus

laboratory experiment, four light increasing growth rates from low treatments including variable light $\left(2.5 \mathrm{~mol}_{\text {photons }} \mathrm{m}^{-2} \mathrm{~d}^{-1}\right)$ to high

(Noonan et al., levels (low: 2.5 , medium: 7.6, and $\left(12.6 \mathrm{~mol}\right.$ photons $\left.\mathrm{m}^{-2} \mathrm{~d}^{-1}\right)$ light (in prep))

high: 12.6 mol photons $\mathrm{m}^{-2} \mathrm{~d}^{-1}$ ) levels (growth rate linearly increased/decreased with cumulative daily light integrals received), cumulative amount of light received affects physiological response

\subsubsection{Benthic PAR data}

The second requirement for developing an index is a consistent and spatio-temporally rich estimate of benthic PAR. We obtained daily bPAR estimates for the GBR study region (Figure 1) from a benthic irradiance model (Magno-Canto et al., 2019; Magno-Canto et al., 2020) that uses ocean color satellite observations from the National Aeronautics and Space Administration (NASA)'s Moderate Resolution Imaging Spectroradiometer (MODIS) aboard the Aqua satellite (NASA Goddard Space Flight Center). The benthic irradiance model estimates the amount of light reaching the seafloor by considering spectrally-varying vertical diffuse light attenuation and variations in depth for each nominal $1 \mathrm{~km}^{2}$ pixel (Magno-Canto et al., 2019; Magno-Canto et al., 2020). Here, we used the daily integrated bPAR data product extracted over a domain within $10.7-24.5^{\circ} \mathrm{S}$ and $142-154^{\circ} \mathrm{E}$ along north-eastern Australia (Figure 1) between July 2002 and December 2019. Following the methods for generating the required daily bPAR data product described in Magno-Canto et al. (2019), we obtained 6322 individual files representing 17.5 years of data. Data aggregation and water quality index calculation were then conducted in R v3.4.1 ( $\mathrm{R}$ Core Team, 2019).

\subsubsection{Developing the benthic light-based water quality index}

\subsubsection{Calculating total relative benthic light stress for each unmasked pixel}

We first defined benthic light stress, $S$, as the cumulative stress due to benthic light levels falling below the defined bPAR threshold, $T$. The value of this threshold, $16 \mathrm{~mol}$ photons $\mathrm{m}^{-2} \mathrm{~d}^{-1}$, forms part of the results of this study and is explained in section 3.1. For any location in each data file where the per pixel MODIS-derived daily benthic PAR value, $b P A R_{d}$, exceeded $T$, we capped at $b P A R_{d}=T$ on that pixel. Locations with missing data points in a $b P A R_{d}$ file were gap-filled using a monthly mean value calculated on that pixel (i.e., $b P A R_{d}$ values on days with data were averaged for each corresponding month).

For each pixel, we then calculated a reference value, $b P A R_{R}$, which was defined as the $95^{\text {th }}$-percentile $b P A R_{d}$ for each calendar month observed over the decade 2003-2013. This reference value was taken to represent the $b P A R_{d}$ that could potentially be achieved in the best possible water quality conditions at that location and time of year. In very deep water, 'sufficient' (high) $b P A R_{d}$ is not achievable regardless of water quality due to attenuation of downwelling irradiance over the pathlength by seawater and constituent matter. In the context that 'high' $b P A R_{d}$ is subjective depending on the body of water considered (e.g., GBR vs. Chesapeake Bay), we regard 'sufficient' $b P A R_{d}$ as values high enough relative to our chosen threshold. In shallow water, high $b P A R_{d}$ should be achievable, as light availability is a function of water column depth and optical properties, however some nearshore areas may be naturally turbid and therefore highly attenuating regardless of human impacts on water quality.

To calculate the relative daily stress due to low light, $S_{d}$, $\left(\mathrm{mol}\right.$ photons $\left.\mathrm{m}^{-2} \mathrm{~d}^{-1}\right)$ for each day and pixel location, we used: 


$$
S_{d}=b P A R_{d}-b P A R_{R}
$$

Equation (1) denotes that when $S_{d}$ is close to zero, there is either sufficient $b P A R_{d}$ (hence, no stress) on that pixel on that day, i. e., no more light stress than observed in the best $5 \%$ of observed conditions for that pixel. $S_{d}$ values $<0$ were set to zero.

The integral of $S_{d}$ over a time-period of interest (seasonal or annual) thus indicates the chronic light stress due to poor water quality experienced at a given location.

\subsubsection{Summarise relative benthic light stress over management zones}

Finally, to obtain $S$ (the cumulative stress due to benthic light levels falling below our defined bPAR threshold, with a unit of mol photons $\mathrm{m}^{-2}$ per year or season), we summed $S_{d}$ spatially over each zone (i.e., combination of six NRM management regions and four shelf water bodies) and temporally for each 'water year' using:

$$
S=\sum_{d=1}^{n} S_{d}
$$

where $n$ is the number of days in the time-period of interest (i.e., $n=365$ for annual integral, or $n=183$ for the number of days in the austral wet season ( 01 November to 30 April) and austral dry season (01 May to 31 October) for each 'water year', respectively).

\subsubsection{Calculating the bPAR index over management zones}

The bPAR index, $I$, for each zone was then obtained as:

$$
I=\sum_{p=1}^{z}\left(S-S_{\max }\right)_{p}
$$

where $z$ is zone and $S_{\max }=T^{*} n$ where $T$ is again the bPAR light threshold and $n$ is the number of days in the integration period (i.e., $S_{\max }$ is the maximum theoretically possible value of $S$ for that pixel). Note that for the Burnett-Mary NRM region, the offshore water body was deep throughout: there were few if any pixels that ever receive sufficient bPAR to support seagrass or coral habitats, hence excluded.

Table 2. Colour-coded scoring system adapted to indicate the levels of light stress.

\begin{tabular}{ccccc}
\hline Grade & Light stress & Description & Numerical criteria & Colour \\
\hline A & No stress & Very good & $>0.8-1.0$ & Dark green \\
B & Low stress & Good & $>0.6-0.8$ & Light green \\
C & Moderate stress & Moderate & $>0.4-0.6$ & Yellow \\
D & High stress & Poor & $>0.2-0.4$ & Orange \\
E & Very high stress & Very poor & $0-0.2$ & Red \\
\hline
\end{tabular}

\subsubsection{Scaling and assigning letter grades}

299 The final scaled bPAR index, I $D P A R$, was then obtained by linearly rescaling $I$ to a value between 0 and 1 to allow unbiased

300 (e.g., equally weighted) comparison of relative benthic light stress values in different zones. The scaled $I_{b P A R}$ values range from 1.0, indicating low benthic light stress (very good water quality) to 0.0 , indicating the maximum observed benthic 
light stress in any season in the record for that zone (very poor water quality). Finally, scaled I $D P A R$ values were mapped onto the five-point (A-E) colour-coded grading scale (Table 2) used in the current GBR Water Quality report cards (Robillot et al., 2018).

2.4 Relating the bPAR index to estimates of catchment-derived loads of total suspended sediments, dissolved inorganic nitrogen and river discharge

For the purpose of relating potential variability in the bPAR index to a specific water quality driver (i.e., turbidity due to increased suspended sediment concentrations, CDOM from freshwater discharge or increased availability of nutrients that can support biological processes that may also reduce light availability), we also considered estimates of total suspended sediment (TSS) loads, dissolved inorganic nutrient (DIN) loads, and river discharge data from major catchment regions that contribute most to the runoff inputs to the GBR. The methods for generating these load estimates are described below and elsewhere (Gruber et al., 2020; Gruber et al., 2019) and form an integral part in mapping the superficial dispersion of land-derived nitrogen and sediment in the GBR as part of the AIMS Inshore Water Quality Marine Monitoring Program. Briefly, the total river discharge for each basin was calculated using an approach that up-scaled available measured gauge flow data (i.e. the flow gauges rarely capture the full basin area and hence underestimate flow from the basin); available Grid-to-Grid (G2G) modelling (covers the Normanby to Mary Basins) from the Bureau of Metrology (Bureau of Meteorology, 2017; Wells et al., 2017) was used to inform the upscale factors for the flow data. An area-correction factor was applied to the four basins north of the Normanby (i.e. not modelled by $\mathrm{G} 2 \mathrm{G}$ ) and for basins which had no available flow data the flow gauge data from the nearest neighbour basin was applied (along with the relationship with the G2G model to produce the upscale factor) to calculate discharge (Gruber et al., 2020).

The TSS loads for the river basins of the GBR were derived from a systematic approach which included: 1 . The measured TSS loads from the Burdekin, Pioneer and Fitzroy basins were compiled from the Great Barrier Reef Catchment Loads Monitoring Program (annual reports each year from 2010: https://www.reefplan.qld.gov.au/tracking-progress/paddockto-reef/modelling-and-monitoring) as well as previous programs from the Burdekin (Kuhnert et al., 2012), Pioneer (Joo et al., 2012); note that for the 2002/03 to 2005/06 water years, an annual mean concentration (AMC) of $112 \mathrm{mg} . \mathrm{L}^{-1}$ was applied to calculate the load for this basin) and Fitzroy (Joo et al., 2012; Packett et al., 2009) basins. As the loads measured at these sites capture $>95 \%$ of the basin area they provide the most accurate measure at these locations; 2 . For the remaining basins with available monitoring data, the AMC data (i.e. load divided by flow) from available load monitoring data within the basin were compared with the Source Catchments model outputs (McCloskey et al., 2017). The most appropriate AMC (or a mean of the monitoring and modelled data) was chosen and multiplied by the annual discharge (calculated from the above method) to formulate an annual load for these basins; 3 . Where no monitoring data were available in the basin, the AMC informed from the Source Catchments model (McCloskey et al., 2017) and data from neighbouring basins with similar climate and geomorphology was coupled with the annual water year river discharge to calculate the TSS load (Gruber et al., 2019). The Source Catchments model produces a load that represents a $\sim 30$-year long term mean load (McCloskey et al., 2017) but excludes annual water year loads.

Like the TSS loads, the DIN loads for the river basins of the GBR were similarly derived from a systematic approach which included: 1. The measured DIN loads from the Burdekin, Pioneer and Fitzroy basins from the same sources listed for the TSS method; 2. The method of (Lewis et al., 2014) was applied to calculate DIN loads for the basins of the Wet Tropics and the Haughton Basin. Briefly, modelled DIN loads in this method were calculated using existing load monitoring data to develop a relationship between the measured loads with flow volumes (at river monitoring sites) and 
the amount of fertiliser applied to calculate the percentage of applied nitrogen fertiliser lost as DIN across various discharge amounts. This relationship is then applied to upscale loads for the entire basin area; 3 . For the remaining basins, similar to the TSS loads method, the AMC data from available load monitoring were compared with the Source Catchments model outputs and the most appropriate AMC (taking into account the cropping area above and below the measured site) was chosen for each basin and multiplied by the annual discharge to formulate an annual load; 4 . Where no monitoring data were available, the AMC informed from the Source Catchments model (McCloskey et al., 2017) and data from neighbouring basins with similar climate and geomorphology was coupled with the annual water year river discharge to calculate the water year loads (Gruber et al., 2019). Resulting TSS and DIN loads and river discharge were presented as stacked bar graphs.

Table 3. Relative contributions of the major rivers considered for each of the NRM regions in estimating loads of total suspended sediment (TSS), dissolved inorganic nutrient (DIN) and discharge.

\begin{tabular}{lcl}
\hline Region (current study) & Region (Fabricius et al., 2016) & \multicolumn{1}{c}{ Relevant rivers } \\
\hline Cape York & Cape York & Normanby, Endeavour, Stewart \\
& North Wet Tropics & $\begin{array}{l}\text { Daintree, Barron, Russell, Mulgrave, } \\
\text { Johnstone, Burdekin (30\% of discharge) }\end{array}$ \\
$\begin{array}{l}\text { Wet Tropics: (North } \\
\text { Wet Tropics + South }\end{array}$ & & $\begin{array}{l}\text { Russell, Mulgrave, Johnstone, Tully, } \\
\text { Wet Tropics) }\end{array}$ \\
& South Wet Tropics & Herbert, Burdekin (50\% of discharge) \\
Dry Tropics & Burdekin & Burdekin \\
Mackay-Whitsunday & Whitsundays & Proserpine, O'Connell, Pioneer \\
Fitzroy & Broad Sound-Pompey, Keppel Bay & Fitzroy \\
Burnett-Mary & Fitzroy-Swain & Burnett \\
\hline
\end{tabular}

We then compared the annual river load estimates and the proposed bPAR index using simple linear regression analysis to highlight the drivers of variability in the bPAR index from year to year. We focused the comparison using the annual $I_{D P A R}$ based on the light threshold for corals and the estimate of the total river loads and discharge relevant for each of the zones. It is important to note that the overall flow and transport of materials from the rivers along the length of the GBR is often northward (Devlin and Brodie, 2005) along the coast (i.e., due to Coriolis effects and SE trade winds) which means that the NRM regions may also receive inputs from other rivers situated in adjacent NRM regions (zones) (Skerratt et al., 2019). The total discharge for each NRM region was hence obtained by aggregating estimates for main influential rivers for each region following Fabricius et al. (2016) (see Table 3). Note, however, that in the present study, estimates for the Fitzroy region are slightly different and that the Wet Tropics NRM region annual load estimate was combined and not separated to north and south sectors as in Fabricius et al. (2016).

\section{Results}

\subsection{Defining a light threshold for calculating benthic light stress}

Considering the ranges of benthic light requirements of both corals and seagrasses described in Section 2.3.1 and examining the inflection point of the P-E curve presented in DiPerna et al. (2018) and the results of Strahl et al. (2019), we employed a benthic PAR threshold of 16 mol photons $\mathrm{m}^{-2} \mathrm{~d}^{-1}$. Ad hoc sensitivity analysis using other benthic light thresholds (i.e., 5, 10 and 14 mol photons $\mathrm{m}^{-2} \mathrm{~d}^{-1}$ ) produced an index with less sensitivity to known regional and temporal variations. We note that the selected $16 \mathrm{~mol}$ photons $\mathrm{m}^{-2} \mathrm{~d}^{-1}$ threshold value represents the maximum amount of benthic light that both target benthic organisms will be able to make use of to attain optimal growth if other environmental 
conditions are optimal, rather than the minimum light below which net productivity will be negative regardless of other conditions. In other words, corals and seagrasses can and do exist in areas where the mean daily light is above or below 16 mol photons $\mathrm{m}^{-2} \mathrm{~d}^{-1}$, but their survival and growth can be expected to be enhanced with increasing daily integrated light up to around $16 \mathrm{~mol}$ photons $\mathrm{m}^{-2} \mathrm{~d}^{-1}$, and not substantially enhanced above this threshold.

\subsection{Cumulative benthic light stress}

The cumulative benthic light stress (S) within the GBR varied strongly both spatially and temporally. Figure 2 shows maps of $\mathrm{S}$ for selected water years highlighting this variability. Benthic light stress consistently showed greater variability in inshore locations compared to offshore areas. For example, the open coastal locations in the 2005 - 2006 'dry' (e.g., period where below average rainfall was recorded by the Australian Bureau of Meteorology) water year (Figure 2a) showed relatively low stress, but indicated considerably higher values in the 'wet' water years 2010 - 2011 (Figure 2b) and $2018-2019$ (Figure 2c).

\subsection{A benthic light-based index of water quality}

\subsubsection{Annual bPAR index}

The timeseries of the annual $I_{D P A R}$ based on the relative benthic light stress showed strong interannual variation as well as spatial variation between the zones (Figure 3). Regional differences followed latitudinal gradients. From north (Cape York) to south (Burnett-Mary), the annual $I_{b P A R}$ showed an overall decreasing trend that was consistent across all the shelf water bodies except the enclosed coastal water body to some extent. Out of all the NRM regions, Cape York consistently showed the best water quality throughout the 2003 to 2019 water years (i.e., indicated the most water years with letter grade A - "very good" bPAR index value).

The annual $I_{D P A R}$ also showed an across-shelf gradient decreasing from offshore to inshore coastal water bodies. Notably, there was an overall higher variability in $I_{D P A R}$ for the two most inshore locations compared to the midshelf and offshore locations across all NRM regions, the latter having consistently excellent water quality conditions. The annual fluctuations in bPAR index values in the inshore water bodies appear strongest from the 2010 water year although some fluctuations in prior years can also be noted particularly in the Dry Tropics and Mackay-Whitsunday NRM regions. Overall, the temporal variations in the annual $I_{b P A R}$ (Figure 3 ) suggest that the strong local influences of nearshore processes that drives light attenuation at depth.

Specific variability in the annual water quality during certain years can further be inferred in the $I_{D P A R}$ timeseries. For example, in the 2010-2011 water year there was a notable decline in the $I_{b P A R}$ across all NRMs (except for the Cape York region). This decline is again most evident in the open coastal water body where the bPAR index grade drops by one step in most NRMs (e.g., "good" (B) to "moderate" (C) in Wet Tropics and Fitzroy) were obtained between the 2009-2010 and 2010-2011 water years. Following this, there were several other similar but smaller declines in $I_{D P A R}$ during the other water years, but interestingly, the variability remained confined within the coastal inshore locations across all NRM regions particularly within the open coastal water body. 


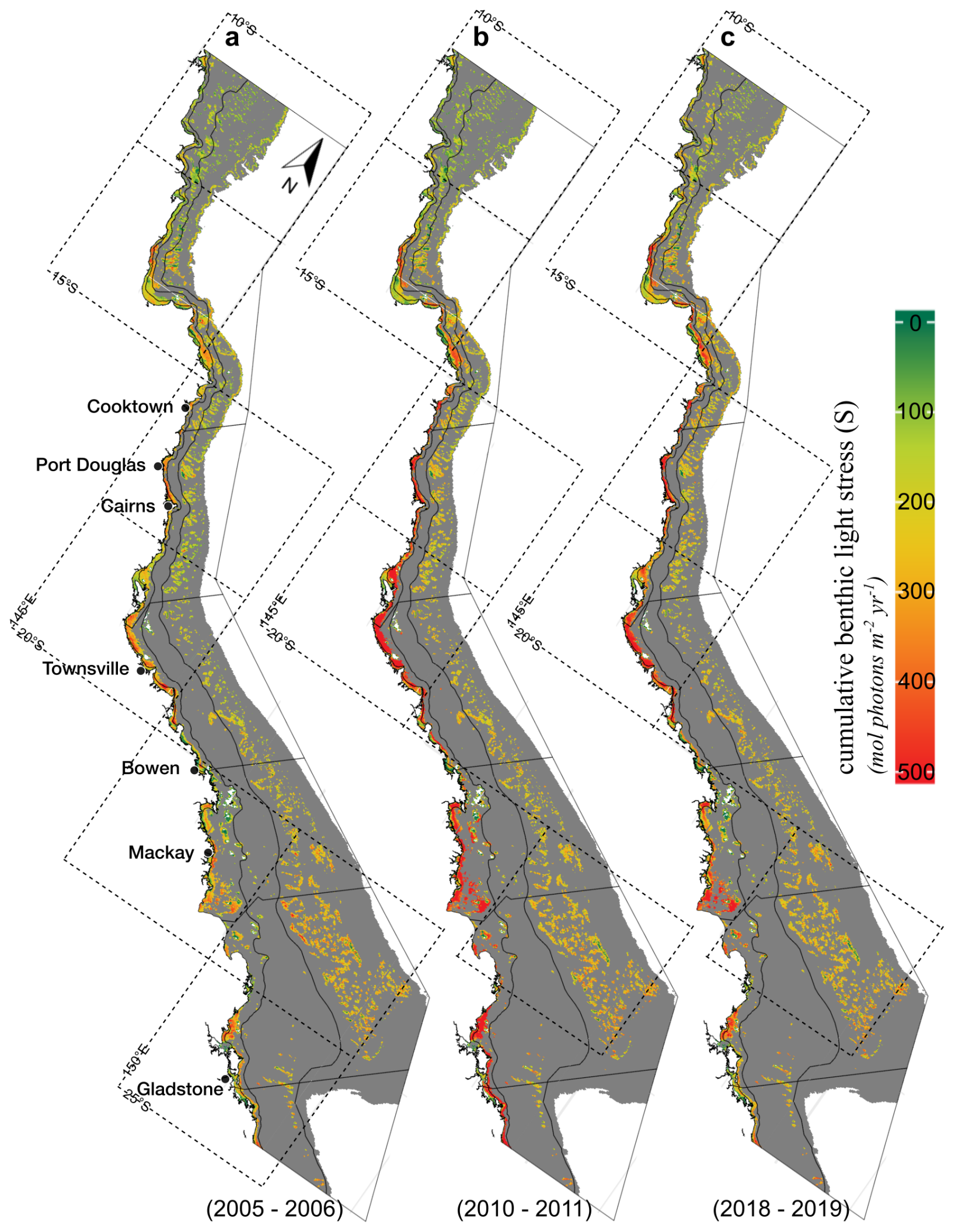

Figure 2. Cumulative (annual) benthic light stress (S) maps for some representative water years: (a) 2005 - 2006, (b) 2010 2011, and (c) 2018 - 2019 highlight the strong spatial and temporal variability in the amount of light stress experienced by corals and seagrasses at each zone within the GBR. Zones are indicated by thin solid lines as in Figure 1. 
Annual $I_{\text {DPAR }}$ calculated over $95^{\text {th }}$ percentile mask
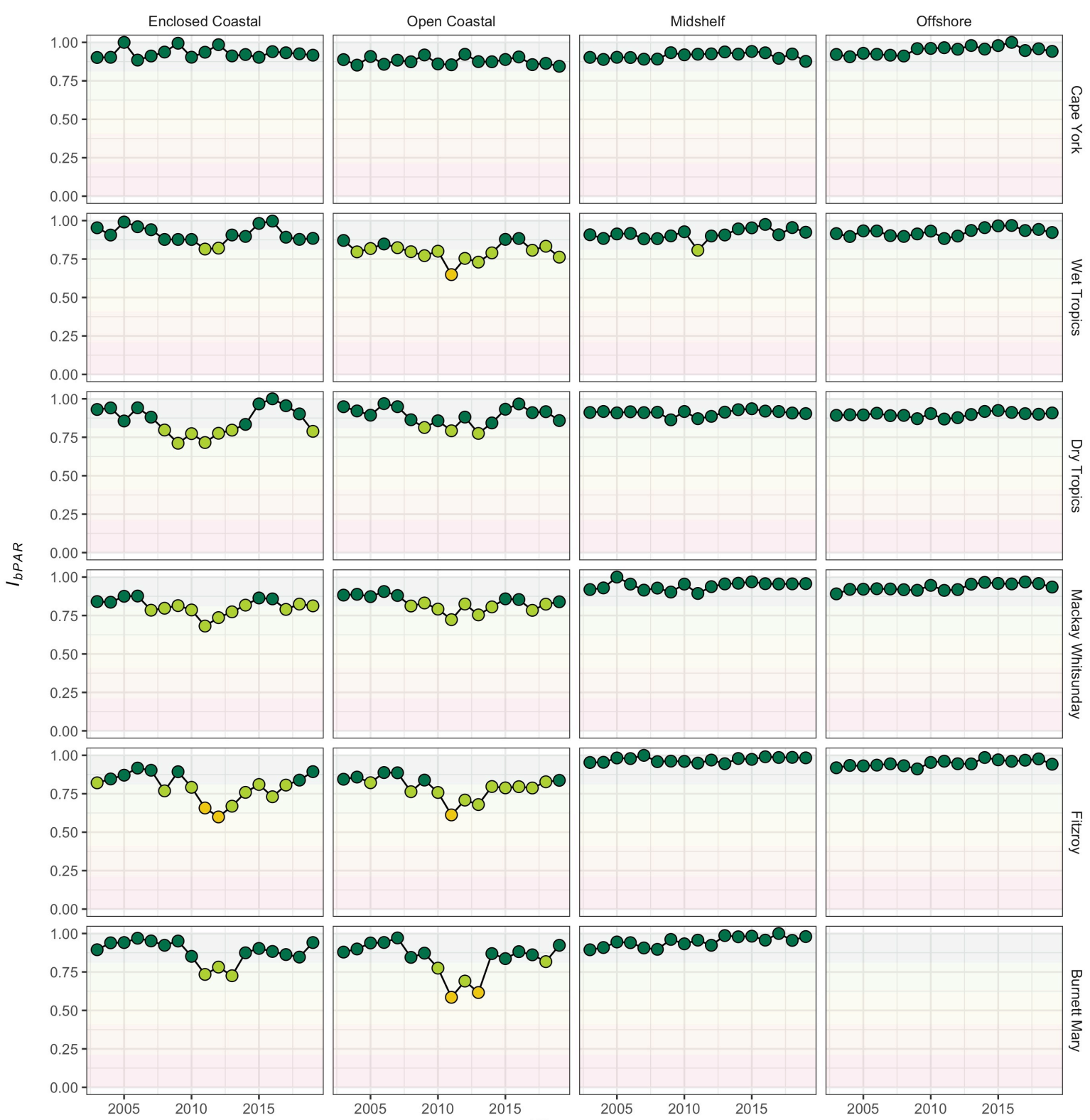

Grade
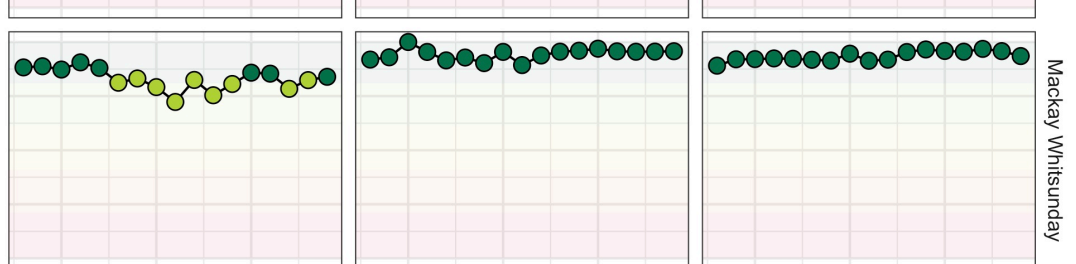

- A

O B

O C

D

O $E$
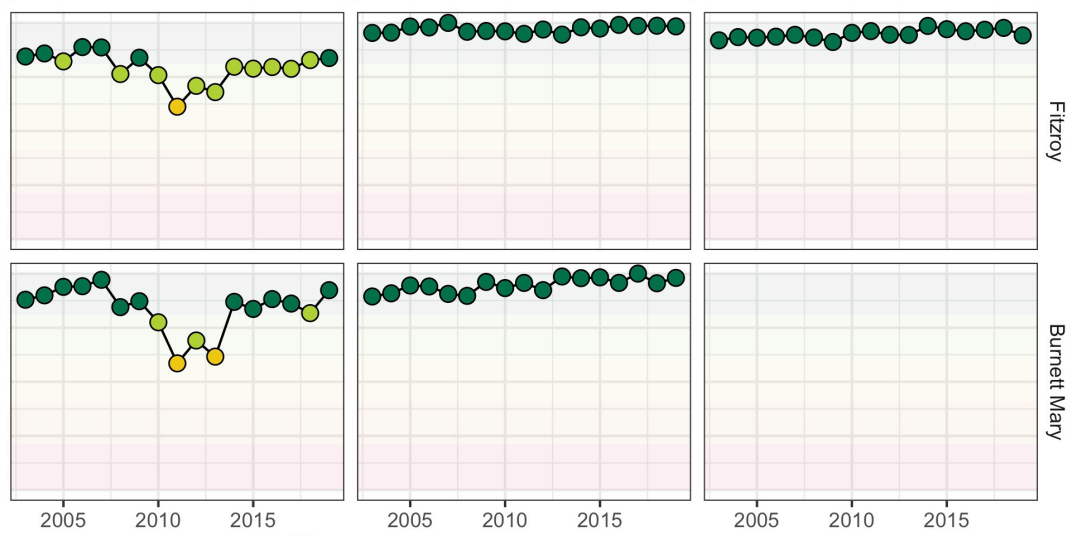

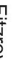

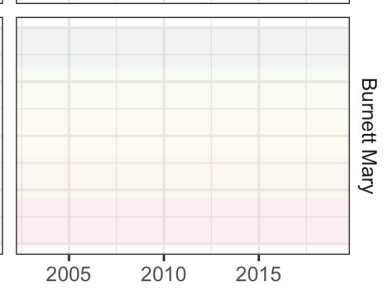

Figure 3. Timeseries of annual scaled bPAR index $\left(I_{b P A R}\right)$ for water years $(2002-2003)$ to (2018 - 2019) over locations within the $95^{\text {th }}$ percentile of bPAR values $\leq 16 \mathrm{~mol}$ photons $\mathrm{m}^{-2} \mathrm{~d}^{-1}$. Colors correspond to letter grades that indicate the quality of the water as: very good (A, dark green), good (B, light green), moderate (C, yellow), poor (D, orange), and very poor (E, red). 
Wet season $I_{\text {DPAR }}$ calculated over $95^{\text {th }}$ percentile mask

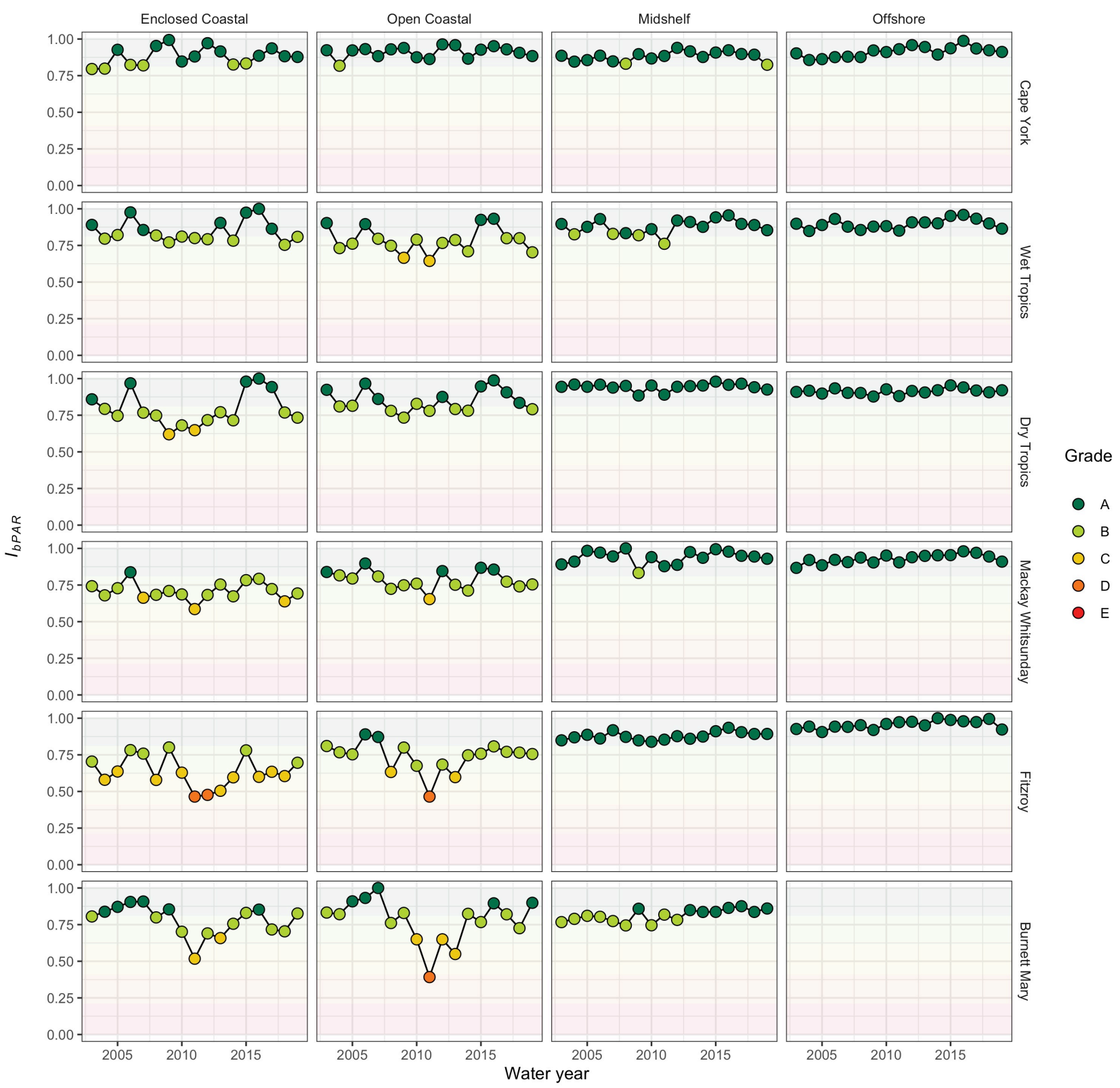

Figure 4. Timeseries of wet-season scaled bPAR index (I $\left.I_{b A R}\right)$ for water years $(2002-2003)$ to $(2018$ - 2019) over locations within the $95^{\text {th }}$ percentile of $b P A R$ values $\leq 16 \mathrm{~mol}$ photons $\mathrm{m}^{-2} \mathrm{~d}^{-1}$ integrated over austral wet-season period (01 November to 30 April during each 'water year'). Color legend same as Figure 3. 
Dry season $I_{\text {DPAR }}$ calculated over $95^{\text {th }}$ percentile mask

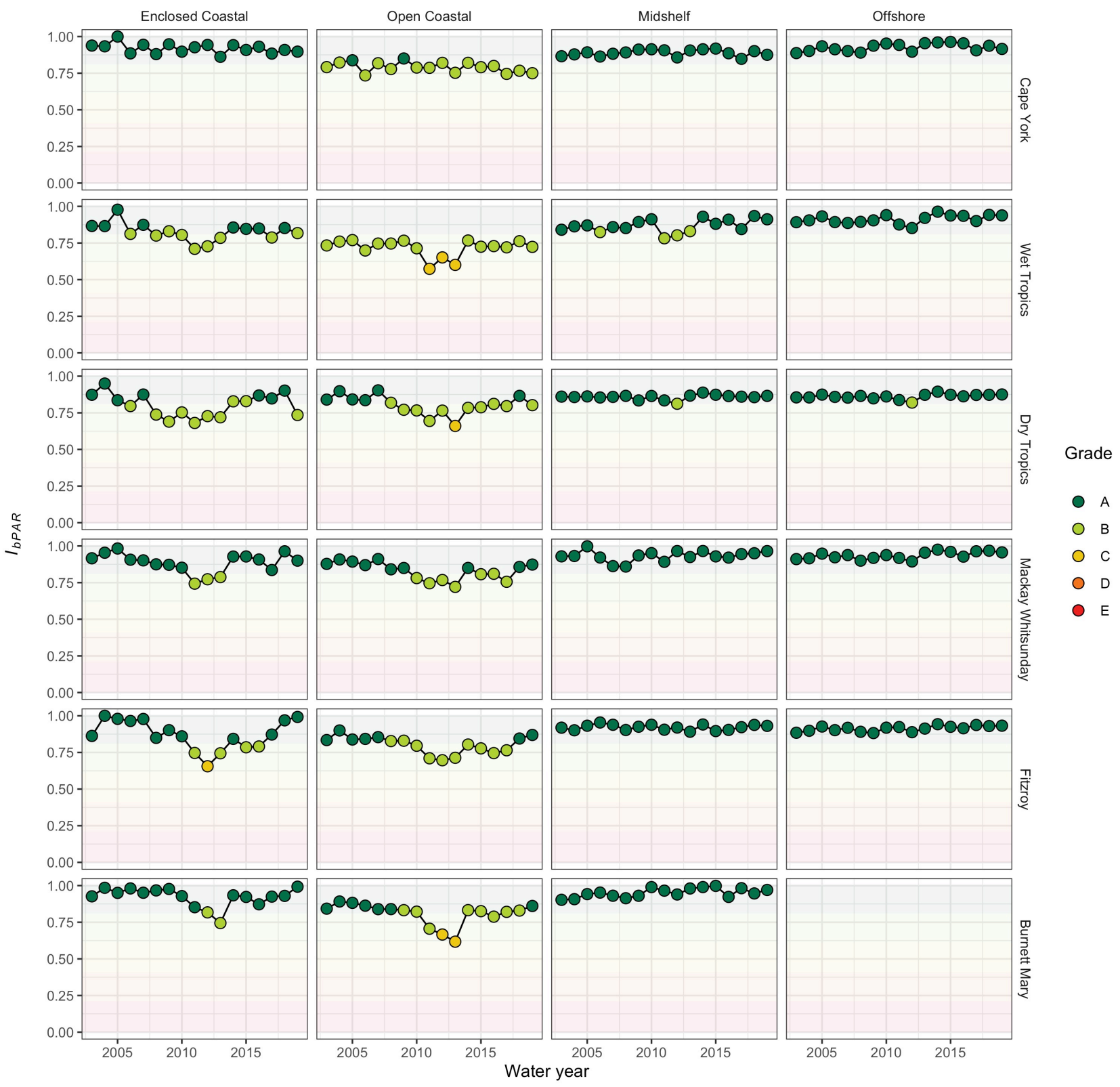

Figure 5. Timeseries of dry-season scaled bPAR index (I IPAR) for water years (2002 - 2003) to (2018 - 2019) over locations within the $95^{\text {th }}$ percentile of $b P A R$ values $\leq 16$ mol photons $m^{-2} d^{-1}$ integrated over austral dry-season period (01 May to 31

October during each 'water year'). Color legend same as Figure 3.

\subsubsection{Seasonal bPAR index}

Inter- and intra-seasonal differences were apparent for the austral wet (Figure 4) and dry (Figure 5) season $I_{b P A R}$. The intra-seasonal patterns also displayed the same north-south latitudinal or across-shelf gradients as also observed in the annual data (Figure 3 ) where the midshelf and offshore water bodies again showed more consistent and less variable $I_{b P A R}$, while the inshore locations (both enclosed coastal and open coastal) showed stronger variability. The timeseries of $I_{b P A R}$ indicated the stronger sensitivity of the nearshore water bodies to long-term reductions in benthic light availability (i.e., lower $I_{b P A R}$ grade for the same 'water year' and zone). 
Inter-seasonal differences between the seasonal indices indicated more pronounced variabilities during the austral wet than the austral dry season similarly with cross-shelf spatial differences being more notable in the two inshore water bodies compared to the midshelf and offshore locations.

\subsection{Annual river discharge, total suspended sediment (TSS) and dissolved inorganic nutrient (DIN) loads}

Distinct variability in the annual river discharge (ML/year) and TSS (kt/year) and DIN (t/year) loads were observed over time for some selected major river systems (Figure 6). In most 'water years', the annual Burdekin River discharge was consistently larger compared to the estimates from the four other rivers (Figure 6a, 6d), although the Fitzroy River estimates are also worth noting as the second largest discharge. Consequently, the highest annual TSS loads were also apparent for the Burdekin River followed closely by the Fitzroy River (Figure 6b, Figure 6e). The other three river systems were less significant in comparison to Burdekin and Fitzroy distinguished by relatively small discharge and TSS loads over the period covering the 2003 to 2019 water years. Nonetheless, the estimates from these three smaller river systems still showed some degree of variability over time.

For the Burdekin River, the highest TSS load was observed during the 2007-2008 water year with almost 15,000 kt/year suspended sediments recorded. Comparable TSS loads for the Burdekin River were also observed the following water year (2008-2009) and in 2018-2019 with almost 11,000 kt/year and $7000 \mathrm{kt} /$ year suspended sediments recorded, respectively. The highest TSS load for Fitzroy River over the period covered occurred in the 2010-2011 water year where about 7,000 kt/year was recorded.
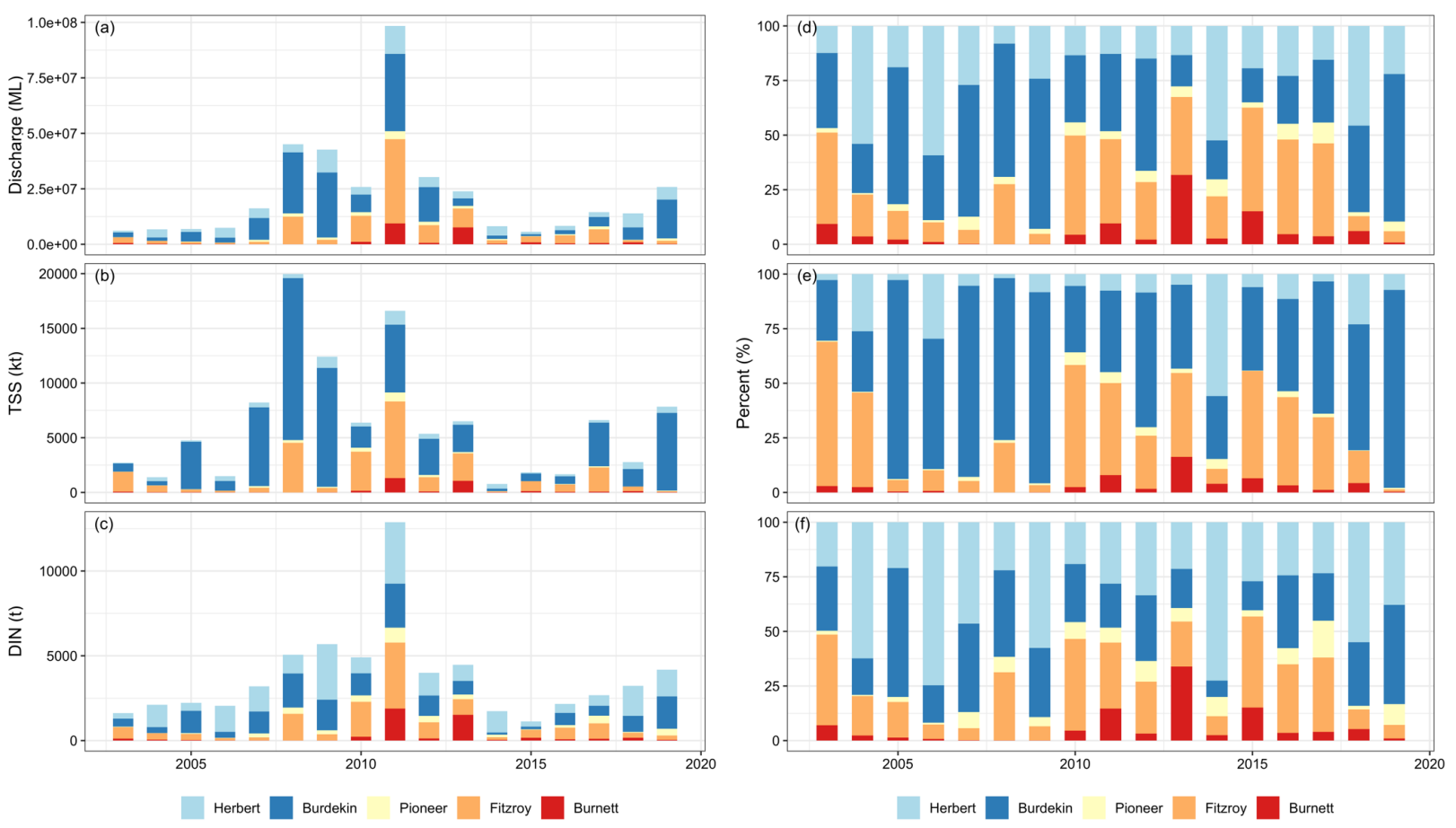

Figure 6. Absolute annual estimates of (a,d) river freshwater discharge, (b,e) total suspended sediment (TSS), and (c,f) dissolved inorganic nutrients (DIN) loads calculated at selected five major rivers found along the length of the GBR. Colors indicate the associated river source.

In terms of DIN loads, the Herbert River appear to contribute most of the catchment-derived nutrients followed very closely by the Burdekin and Fitzroy rivers (Figure 6c, 6f). The largest cumulative DIN load estimates throughout the 
period considered were recorded in the 2010-2011 water year with comparable loads obtained for Fitzroy and Herbert rivers during that water year.

\subsection{Regression analysis of annual river loads and the bPAR index}

Simple regression analysis showed a strong relationship between annual $I_{b P A R}$ and annual estimates of river discharge and loads (both TSS and DIN) with relatively steeper slope in the inshore locations (enclosed coastal and open coastal waterbodies), particularly in the southern NRM regions, compared to the midshelf and offshore waters (Table 4 and Figure 7), consistent with the latitudinal and cross-shelf gradients observed in the IDPAR time series. Specifically, strongest correlations (based on $\mathrm{R}^{2}$ values summarised in Table 4) between $I_{D P A R}$ and Discharge were noted in the inshore locations for Mackay Whitsunday enclosed coastal and Fitzroy open coastal zones although north of these zones, respectively, Dry Tropics enclosed coastal and Mackay Whitsunday open coastal zones also showed comparable strong correlations. On the midshelf and open coastal water bodies, the strongest correlations between IDPAR and Discharge were noted in the Wet Tropics but the relationship obtained for Dry Tropics was also notable.

The correlations between $I_{b P A R}$ and TSS load showed a similar pattern except that the highest $\mathrm{R}^{2}$ values for the midshelf and offshore waterbodies were noted in the Cape York NRM instead.

The strongest correlations between $I_{D P A R}$ and DIN load were also noted in the inshore locations in the Mackay Whitsundayenclosed coastal and Burnett Mary-open coastal zones while Wet Tropics showed highest correlation coefficients in the water bodies away from the coast.

Overall, the relationship between $I_{b P A R}$ and the three river-derived parameters (discharge, TSS and DIN) appear to be generally stronger in the inshore locations for the southern NRMs (Mackay Whitsundays, Fitzroy and Burnett Mary) and away from the coast for the northern NRMs (Dry and Wet Tropics and Cape York). However, the correlation coefficients obtained for the Dry Tropics-enclosed coastal for all three parameters against the $I_{b P A R}$ are also comparably strong, diluting this correlation boundary.

Table 4. Summary of linear regression statistics of $I_{b P A R}$ versus DIN, freshwater discharge and TSS for each zone. Highlighted cells indicate the strongest correlation (i.e., highest the $R^{2}$ value) for each category and zone. Values in bold indicate very close $R^{2}$ values to the highest $R^{2}$.

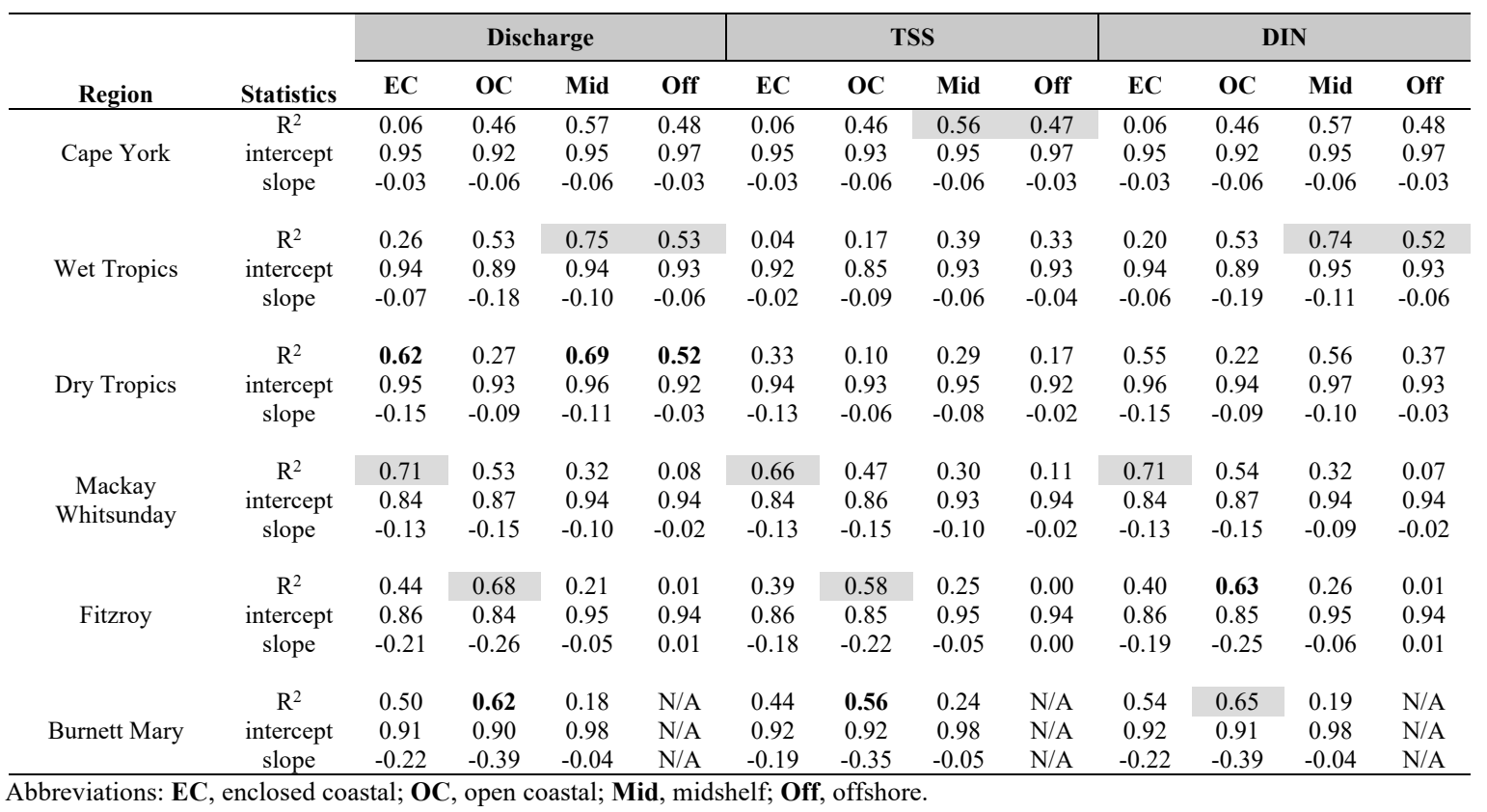




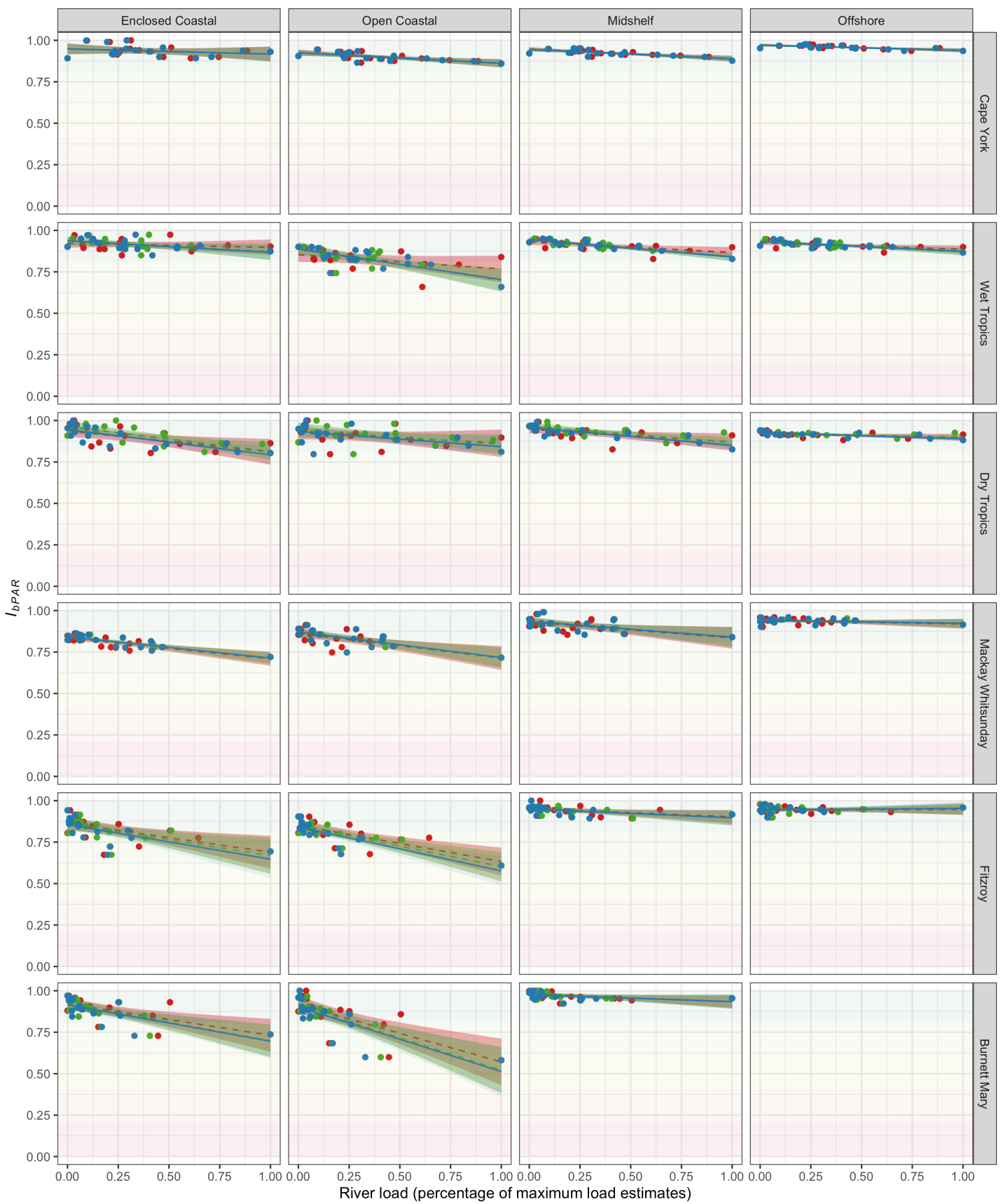

Figure 7. Scatterplots of scaled annual river loads of freshwater (blue-filled circles), DIN (green-filled circles) and TSS (redfilled circles) for each region versus annual $I_{b P A R}$ for each zone. For each region, river loads are scaled from 0 (the minimum observed load) to 1 (the maximum observed load for that region). Also shown are the 95\% confidence interval indicated as shaded areas: TSS (red), DIN (green), and freshwater (blue) with the mean fitted line: TSS (red dashed line), DIN (green dashed line), and river freshwater discharge (blue solid line).

\section{Discussion}

4.1 Drivers and patterns of variations in benthic light and the bPAR index

This study presents a novel method for calculating a index of water quality in the GBR that is responsive to changes in the quantity of light reaching corals and seagrasses. We used spatiotemporally-rich satellite-derived bPAR as a core input data along with a benthic light threshold to calculate the cumulative benthic light stress parameter, $S$, the cumulative 
amount of light lost (relative to a maximum benthic light threshold) where corals and seagrasses were potentially photolimited due to reduced light availability (i.e., from poor water quality). Many locations nearshore indicated as much as $500 \mathrm{~mol}_{\text {photons }} \mathrm{m}^{-2} \mathrm{yr}^{-1}$ growth potential lost from light limitation stress (Figure 2). The $S$ parameter served as the basis of the new bPAR index reported here as annual or seasonal values scaled for each NRM region and shelf water body between 0 and 1 indicating 'very poor' (very high light stress) and 'very good' (no light stress) water quality conditions, respectively. Our results showed that the benthic light stress and hence the proposed benthic light-based index ( $\left.I_{D P A R}\right)$ vary both spatially and temporally within the six NRM focus regions and four coastal water bodies. Latitudinal patterns can be generalised as decreasing from north (Cape York) to south (Burnett Mary) while the cross-shelf gradients generally decrease towards the coast (e.g., higher benthic light stress calculated nearshore).

The observed patterns are closely related to the dynamics of key water quality drivers that may include river discharge (and the related factors such as suspended sediment concentrations) and potentially to occurrence of atmospheric and physical disturbances (cyclones, wind, wave and tidal mixing) as well as the local oceanography that governs the transport and hydrodynamics of river or flood plumes within the shelf. While the inshore locations typically receive higher daily light doses due to greater potential for light penetration because of shallow bathymetry (Ackleson, 2003), the annual light stress maps (Figure 2Error! Reference source not found.) and $I_{b P A R}$ timeseries (Figure 3 to Figure 5) showed that these coastal locations are most vulnerable to declines in benthic light levels compared to the midshelf and offshore locations. River flood plumes within the GBR can, in very wet years, simultaneously occur from the Cape York to Burnett-Mary regions but mostly impact areas within $20 \mathrm{~km}$ inshore, occasionally reaching beyond the midshelf regions (Devlin et al., 2012) and often spread in a band up to $50 \mathrm{~km}$ from the coast (Devlin and Brodie, 2005). The overall patterns we obtained in this study were also consistent with previous simulations (Skerratt et al., 2019) of the spatial distribution of some water quality parameters directly related to or considered a proxy for light availability at depth. For example, simulated $Z_{\text {sd }}$ from Skerratt et al. (2019) was generally greater offshore and decreased as distance from shore decreased, and from north to south, while $\mathrm{Chl} a$ concentration increased from north to south and from outer to inner coastal regions. Higher concentrations of Chl $a$ are generally associated with higher light attenuation (thus, reduced light availability) and in the context of this study, high light-stress (or increased stress from light attenuation) and a low IbPAR.

Temporal differences in water quality and light reductions were also detected by our new index as a response to the terrestrial inputs delivered into the shelf via river discharge. Inter-seasonally, the austral wet season is generally associated with elevated river discharge in the Queensland tropical region, resulting in lower water clarity and increased light stress from light attenuation. The resulting austral wet season indices (Figure 4) indicated that for most of the southern NRMs, water quality conditions returned (within two years) to the "moderate to good" range within the inshore water bodies after marked decline during the 2010 - 2011 water year associated with high river discharges and TC Yasi. Before this, however, steady decline in water quality conditions even before 2011 can also be noted in the time series. Coincidentally, the recent inshore Marine Monitoring Program report (Gruber et al., 2019) have indicated that inshore $Z_{\text {sd }}$ in most NRMs have declined since 2005 and have not been meeting guideline values based on in situ water quality data collected at several point locations within the GBR nearshore waterbodies during the austral wet season. At intra-annual time scales, other processes may add variability to $I_{D P A R}$ that may also be related to changing nutrient and suspended sediment concentrations. These temporal patterns reflect the combined effects of the transport of river-derived materials clearly indicating its role in driving light reduction (Schaffelke et al., 2012) and the influence of wind and wave driven resuspension of material from the seafloor and biological response from increased nutrient availability especially in the inshore areas. 
River discharge is a major pathway for transport of land-derived sediments and pollutants into the Reef lagoon (Brodie et al., 2012; Devlin and Brodie, 2005; Petus et al., 2014). Its transport often leads to increased turbidity and decreased water clarity in regions offshore from the river mouths. The estimates of annual TSS loads for some of the major rivers (Figure 6) showed clear concurrence with the episodic increases in river discharge following flood and cyclone events. The 2011 water year (which encompasses the 2010-11 wet season), for example, was associated with unprecedented rain and flooding in Queensland as early as November - December 2010 (associated with Tropical Cyclone (TC) Tasha) and the passing of severe TC Yasi in early January 2011 that further exacerbated state-wide flooding. Wet season $I_{b P A R}$ during the same water year also reflects the immediate influence of these major events but also the subsequent effects related to resuspension and retention of flood-derived materials (Neil et al., 2002; Orpin and Ridd, 2012) and potentially floodinduced biological productivity (Devlin and Schaffelke, 2009) as reduced water quality due to light reduction across most of the zones. The role of potential drivers of variability in $I_{b P A R}$ was explored via linear regression analysis (Figure 7 and Table 4) which confirmed the higher influence of river-derived materials in the inshore locations especially in the southern NRMs and in the water bodies away from the coast in most of the northern NRMs. These patterns were indicative of the net northward transport of anthropogenic materials in southern hemisphere coastlines (via Ekman transport and Coriolis effects). The higher correlations noted for the Mackay Whitsunday and Fitzroy inshore zones are suggestive of the chronic effects that drive light reduction from rivers located south of these NRMs, mainly the Fitzroy River and Burnett Mary River, (see Figure 1 for relative locations of NRMs and rivers) with materials generally retained nearshore (and resuspended) by local wind-driven and tidal circulations and potentially demarcated by oceanic intrusions from north and central regions of the lagoon. The notably stronger correlations between $I_{b P A R}$ and TSS in the midshelf and offshore waterbodies for most of the northern NRMs may be related to chronic light reductions at depth due to resuspension of bottom sediment materials especially during strong wind conditions.

Variability in the bPAR index was mostly confined to the inshore (and to some extent, the midshelf) water bodies in most NRM regions (Devlin et al., 2012). This not only underscores the overall exposure risk of the nearshore regions to light reduction as a likely response to increased turbidity and high CDOM absorption due to land-based runoffs from nearby catchments but also emphasises three key points. Firstly, it lends support to current policies and measures (i.e., Reef 2050 Water Quality Improvement Plan 2017-2022) that aim to improve the quality of the water that enters the GBR lagoon. Secondly, the movement of river plumes are indeed generally demarcated along the inner shelf (i.e., due to northward net transport of materials due to SE winds and Coriolis forcings) and while plumes may occasionally move out to the midor outer shelf during larger events that coincide with slack or northerly winds, pollutants that can cause light reduction beyond inshore regions are probably dispersed more quickly or deposited in the deeper zones which do not get resuspended again except potentially during strong currents generated by cyclonic conditions (Larcombe and Carter, 2004). This underscores the complex nature and interconnectedness of the many factors that determine light availability within the GBR which are important to consider if we are to better manage water quality and land practices within the GBR. Lastly and more importantly, our results clearly demonstrate the sensitivity of the proposed index to capture light variabilities that have direct impact on coral and seagrass ecosystems of the GBR, hence, also highlight the potential of the proposed new index as an alternative water quality metric in place of/or to complement the currently used metric based on combined $\mathrm{Chl} a$ and $\mathrm{Z}_{\mathrm{sd}}$ sub-indicator data that also maintains the spatial and temporal data requirements essential in studying a region as vast as the GBR. 
We have presented a new method for developing an index of water quality based on the amount of benthic light reaching corals and seagrasses. Our method uses two core pieces of information. First, GBR-wide estimates of $b P A R_{d}$ obtained from a remote sensing algorithm allowed assessment of historical light conditions within the GBR on a near-daily timestep over the 17.5 years from July 2002 to December 2019. Second, we specified a combined (coral and seagrass) benthic light threshold that denotes the maximum amount of light that key coral and seagrass species can potentially use to maintain growth, above which very little increase in photosynthetic efficiency can be expected. We combined these two sets of information to derive the relative benthic light stress parameter - the stress on benthic habitats due to low light conditions. This parameter was aggregated over each water year for each $1 \mathrm{~km} \mathrm{x} 1 \mathrm{~km}$ pixels, scaled to a value between 0 and 1 for each management region, and then mapped out to a letter grade, A to E to indicate 'very good' (no light stress) to 'very poor' (very high light stress) water quality conditions which aligned with the current format used in GBR water quality report cards.

The annual and seasonal $I_{b P A R}$ calculated for the six NRM focus regions (Cape York to Burnett-Mary) and four water bodies (enclosed coastal to offshore) showed strong spatial and temporal variability characterised by an overall latitudinal gradient that decreases from north (Cape York) to south (Burnett Mary) and a cross-shelf gradient that improves with distance from the coast. The overall patterns of the $I_{b P A R}$ obtained were indicative of strong response to known drivers of water quality within the GBR (e.g., variability of river discharge and associated total suspended sediment loads and dissolved organic matter, cyclone and weather-related flood events, and the transport (hydrodynamics) of flood plume in the marine environment) and emphasises the importance of robust monitoring tools able to detect exposure of relevant benthic ecosystems to these drivers to better inform water quality management policies implemented within the GBR. The sensitivity of the proposed method to changes in water quality highlights the skill of the new index to map declines in light availability and more importantly demonstrates its potential as a more robust alternative water quality metric to what is currently used, $Z_{s d}$, in GBR Reef Report Cards. The new proposed index accounts for variations in bathymetry as well as the quality and quantity of light and employs a threshold that is directly relevant to photobiology. It therefore relates much more directly to ecological outcomes for corals and seagrasses than other water quality metrics such as turbidity or $\mathrm{Z}_{\mathrm{sd}}$.

Ongoing access to the underlying algorithm used to derive estimates of bPAR from satellite remote sensing observations is currently planned to be made available through existing data infrastructure within Australia (e.g., via Open Data Cube (ODC) initiative under Geoscience Australia's Digital Earth Australia and ocean color data processing stream at the CSIRO's Oceans and Atmosphere, Climate Science Centre) and the wider community (e.g., via NASA's SeaDAS processing software).

Benthic PAR predictions can also be obtained from the GBR eReefs biogeochemical model, which will allow the bPAR index to be calculated for counter-factual land management scenarios, to assist with decision support for GBR policy. It is anticipated that automation of the bPAR index will facilitate its uptake and use in ongoing monitoring and management of the GBR. 
This project is supported with funding from the Australian Government's National Environmental Science Program (NESP) Tropical Water Quality (TWQ) Hub and the AIMS@JCU PhD scholarship with additional support from the Australian Institute of Marine Science and James Cook University.

\section{References}

Ackleson, S.G., 2003. Light in shallow waters: A brief research review. Limnology and Oceanography 48, $323-328$.

Alvarez-Romero, J.G., Devlin, M., da Silva, E.T., Petus, C., Ban, N.C., Pressey, R.L., Kool, J., Roberts, J.J., CerdeiraEstrada, S., Wenger, A.S., Brodie, J., 2013. A novel approach to model exposure of coastal-marine ecosystems to riverine flood plumes based on remote sensing techniques. Journal of Environmental Management 119, 194-207.

Bessell-Browne, P., Negri, A.P., Fisher, R., Clode, P.L., Jones, R., 2017. Impacts of light limitation on corals and crustose coralline algae. Scientific Reports 7, 11553.

Brando, V.E., Dekker, A.G., Park, Y.J., Schroeder, T., 2012. Adaptive semianalytical inversion of ocean color radiometry in optically complex waters. Appl. Opt. 51, 2808-2833.

Brodie, J.E., Kroon, F.J., Schaffelke, B., Wolanski, E.C., Lewis, S.E., Devlin, M.J., Bohnet, I.C., Bainbridge, Z.T., Waterhouse, J., Davis, A.M., 2012. Terrestrial pollutant runoff to the Great Barrier Reef: An update of issues, priorities and management responses. Marine Pollution Bulletin 65, 81-100.

Bureau of Meteorology, 2017. eReefs Catchments: simulations, nowcasts, and forecasts of water quantity and quality flowing to the Great Barrier Reef, Final Report, eReefs Project Phase 3, Great Barrier Reef Foundation, Brisbane, QLD Australia.

Cacciapaglia, C., van Woesik, R., 2016. Climate-change refugia: shading reef corals by turbidity. Global Change Biology 22, 1145-1154.

Chartrand, K.M., Bryant, C.V., Carter, A.B., Ralph, P.J., Rasheed, M.A., 2016. Light Thresholds to Prevent Dredging Impacts on the Great Barrier Reef Seagrass, Zostera muelleri ssp. capricorni. Frontiers in Marine Science 3.

Collier, C., Chartrand, K., Honchin, C., Fletcher, A., Rasheed, M., 2016a. Light thresholds for seagrasses of the GBR: a synthesis and guiding document. Including knowledge gaps and future priorities, Report to the National Environmental Science Programme. Reef and Rainforest Research Centre Limited, p. 41.

Collier, C., Waycott, M., 2009. Drivers of change to seagrass distributions and communities on the Great Barrier Reef: literature review and gaps analysis. Reef and Rainforest Research Centre.

Collier, C.J., Adams, M.P., Langlois, L., Waycott, M., O’Brien, K.R., Maxwell, P.S., McKenzie, L., 2016b. Thresholds for morphological response to light reduction for four tropical seagrass species. Ecological Indicators 67, 358-366.

Collier, C.J., Waycott, M., McKenzie, L., 2012a. Light thresholds derived from seagrass loss in the coastal zone of the northern Great Barrier Reef, Australia. Ecological Indicators 23, 211-219.

Collier, C.J., Waycott, M., Ospina, A.G., 2012b. Responses of four Indo-West Pacific seagrass species to shading. Marine Pollution Bulletin 65, 342-354.

Commonwealth of Australia, 2015. Reef 2050 long-term sustainability plan.

Cooper, T.F., Uthicke, S., Humphrey, C., Fabricius, K.E., 2007. Gradients in water column nutrients, sediment parameters, irradiance and coral reef development in the Whitsunday Region, central Great Barrier Reef. Estuarine, Coastal and Shelf Science 74, 458-470. 
De'ath, G., Fabricius, K., 2010. Water quality as a regional driver of coral biodiversity and macroalgae on the Great Barrier Reef. Ecological Applications 20, 840-850.

Deloitte Access Economics, 2013. Economic contribution of the Great Barrier Reef, Great Barrier Reef Marine Park Authority Townsville.

Dennison, W.C., 1987. Effects of light on seagrass photosynthesis, growth and depth distribution. Aquatic Botany 27 , $15-26$.

Devlin, M., McKinna, L., Alvarez-Romero, J., Petus, C., Abott, B., Harkness, P., Brodie, J., 2012. Mapping the pollutants in surface riverine flood plume waters in the Great Barrier Reef, Australia. Marine pollution bulletin 65, 224-235.

Devlin, M., Petus, C., da Silva, E., Tracey, D., Wolff, N., Waterhouse, J., Brodie, J., 2015. Water quality and river plume monitoring in the Great Barrier Reef: an overview of methods based on ocean colour satellite data. Remote Sensing 7 , 12909.

Devlin, M., Schaffelke, B., 2009. Spatial extent of riverine flood plumes and exposure of marine ecosystems in the Tully coastal region, Great Barrier Reef. Marine and Freshwater Research 60, 1109-1122.

Devlin, M.J., Brodie, J., 2005. Terrestrial discharge into the Great Barrier Reef Lagoon: nutrient behavior in coastal waters. Marine Pollution Bulletin 51, 9-22.

DiPerna, S., Hoogenboom, M., Noonan, S., Fabricius, K., 2018. Effects of variability in daily light integrals on the photophysiology of the corals Pachyseris speciosa and Acropora millepora. PLOS ONE 13, e0203882.

Fabricius, K.E., 2005. Effects of terrestrial runoff on the ecology of corals and coral reefs: review and synthesis. Marine Pollution Bulletin 50, 125-146.

Fabricius, K.E., De'ath, G., Humphrey, C., Zagorskis, I., Schaffelke, B., 2013. Intra-annual variation in turbidity in response to terrestrial runoff on near-shore coral reefs of the Great Barrier Reef. Estuarine, Coastal and Shelf Science $116,57-65$.

Fabricius, K.E., Logan, M., Weeks, S., Brodie, J., 2014. The effects of river run-off on water clarity across the central Great Barrier Reef. Marine Pollution Bulletin 84, 191-200.

Fabricius, K.E., Logan, M., Weeks, S.J., Lewis, S.E., Brodie, J., 2016. Changes in water clarity in response to river discharges on the Great Barrier Reef continental shelf: 2002-2013. Estuarine, Coastal and Shelf Science 173, A1-A15.

Fabricius, K.E., Okaji, K., De'ath, G., 2010. Three lines of evidence to link outbreaks of the crown-of-thorns seastar Acanthaster planci to the release of larval food limitation. Coral Reefs 29, 593-605.

Fisher, R., Bessell-Browne, P., Jones, R., 2019. Synergistic and antagonistic impacts of suspended sediments and thermal stress on corals. Nature Communications 10, 2346.

Furnas, M.M., 2003. Catchments and corals: terrestrial runoff to the Great Barrier Reef. Australian Institute of Marine Science \& CRC Reef Research Centre.

Gattuso, J.-P., Gentili, B., Duarte, C.M., Kleypas, J.A., Middelburg, J.J., Antoine, D., 2006. Light availability in the coastal ocean: impact on the distribution of benthic photosynthetic organisms and contribution to primary production. Biogeosciences Discussions 3, 895-959.

Great Barrier Marine Park Authority, 2010a. Water quality guidelines for the Great Barrier Reef Marine Park. Great Barrier Marine Park Authority, Townsville.

Great Barrier Marine Park Authority, 2010b. Water quality guidelines for the Great Barrier Reef Marine Park (Revised Edition), Revised Edition ed. Great Barrier Reef Marine Park Authority, Townsville, Queensland.

Gruber, R., Waterhouse, J., Logan, M., Petus, C., Howley, C., Lewis, S., Tracey, D., Langlois, L., Tonin, H., Skuza, M., Costello, P., Davidson, J., Gunn, K., Lefevre, C., Moran, D., Robson, B., Shanahan, M., Zagorskis, I., Shellberg, J., 
Neilen, A., 2020. Marine Monitoring Program: Annual Report for Inshore Water Quality Monitoring 2018-19, Report for the Great Barrier Reef Marine Park Authority, Great Barrier Reef Marine Park Authority, Townsville.

Gruber, R., Waterhouse, J., Logan, M., Petus, C., Howley, C., Lewis, S., Tracey, D., Langlois, L., Tonin, H., Skuza, M., Costello, P., Davidson, J., Gunn, K., Lefevre, C., Shanahan, M., Wright, M., Zagorskis, I., Kroon, F., Neilen, A., 2019. Marine Monitoring Program: Annual report for inshore water quality monitoring 2017-18, Report for the Great Barrier Reef Marine Park Authority.

Hughes, T.P., Kerry, J.T., Álvarez-Noriega, M., Álvarez-Romero, J.G., Anderson, K.D., Baird, A.H., Babcock, R.C., Beger, M., Bellwood, D.R., Berkelmans, R., Bridge, T.C., Butler, I.R., Byrne, M., Cantin, N.E., Comeau, S., Connolly, S.R., Cumming, G.S., Dalton, S.J., Diaz-Pulido, G., Eakin, C.M., Figueira, W.F., Gilmour, J.P., Harrison, H.B., Heron, S.F., Hoey, A.S., Hobbs, J.-P.A., Hoogenboom, M.O., Kennedy, E.V., Kuo, C.-y., Lough, J.M., Lowe, R.J., Liu, G., McCulloch, M.T., Malcolm, H.A., McWilliam, M.J., Pandolfi, J.M., Pears, R.J., Pratchett, M.S., Schoepf, V., Simpson, T., Skirving, W.J., Sommer, B., Torda, G., Wachenfeld, D.R., Willis, B.L., Wilson, S.K., 2017. Global warming and recurrent mass bleaching of corals. Nature 543, 373.

Hughes, T.P., Kerry, J.T., Simpson, T., 2018. Large-scale bleaching of corals on the Great Barrier Reef. Ecology 99, 501501.

Hurrey, L.P., Pitcher, C.R., Lovelock, C.E., Schmidt, S., 2013. Macroalgal species richness and assemblage composition of the Great Barrier Reef seabed. Marine Ecology Progress Series 492, 69-83.

Jones, R., Giofre, N., Luter, H.M., Neoh, T.L., Fisher, R., Duckworth, A., 2020. Responses of corals to chronic turbidity. Scientific Reports 10, 4762.

Joo, M., Raymond, M.A.A., McNeil, V.H., Huggins, R., Turner, R.D.R., Choy, S., 2012. Estimates of sediment and nutrient loads in 10 major catchments draining to the Great Barrier Reef during 2006-2009. Marine Pollution Bulletin $65,150-166$.

Kirk, J.T.O., 2011. Light and Photosynthesis in Aquatic Ecosystems, 3rd Ed. Cambridge University Press.

Kleypas, J.A., 1997. Modeled estimates of global reef habitat and carbonate production since the Last Glacial Maximum. Paleoceanography 12, 533-545.

Kroon, F.J., 2012. Towards ecologically relevant targets for river pollutant loads to the Great Barrier Reef. Marine Pollution Bulletin 65, 261-266.

Kuhnert, P.M., Henderson, B.L., Lewis, S.E., Bainbridge, Z.T., Wilkinson, S.N., Brodie, J.E., 2012. Quantifying total suspended sediment export from the Burdekin River catchment using the loads regression estimator tool. Water Resour. Res. 48 .

Larcombe, P., Carter, R.M., 2004. Cyclone pumping, sediment partitioning and the development of the Great Barrier Reef shelf system: a review. Quaternary Science Reviews 23, 107-135.

Leahy, S.M., Kingsford, M.J., Steinberg, C.R., 2013. Do Clouds Save the Great Barrier Reef? Satellite Imagery Elucidates the Cloud-SST Relationship at the Local Scale. PLOS ONE 8, e70400.

Lewis, S., Brodie, J., Endo, G.G.K., Lough, J., Bainbridge, Z., 2014. Synthesizing Historical Land Use Change, Fertiliser and Pesticide Usage and Pollutant Load Data in the Regulated Catchments to Quantify Baseline and Changing Pollutant Loads Exported to the Great Barrier Reef, Centre for Tropical Water \& Aquatic Ecosystem Research (TropWATER) Technical Report 14/20, James Cook University, Townsville, p. 105.

Logan, M., Fabricius, K., Weeks, S., Canto, M., Noonan, S., Wolanski, E., Brodie, J., 2013. The relationship between Burdekin River discharges and photic depth in the central Great Barrier Reef, Report to the National Environmental Research Program. Reef and Rainforest Research Centre Limited, Cairns p. 29 pp.

Lucas, P., Webb, T., Valentine, P., Marsh, H., 1997. The outstanding universal value of the Great Barrier Reef world heritage area. Great Barrier Reef Marine Park Authority, Townsville. 
Magno-Canto, M.M., McKinna, L.I.W., Robson, B.J., Fabricius, K.E., 2019. Model for deriving benthic irradiance in the Great Barrier Reef from MODIS satellite imagery. Opt. Express 27, A1350-A1371.

Magno-Canto, M.M., McKinna, L.I.W., Robson, B.J., Fabricius, K.E., Garcia, R., 2020. Model for deriving benthic irradiance in the Great Barrier Reef from MODIS satellite imagery: erratum. Opt. Express 28, 27473-27475.

McCloskey, G., Waters, D., Baheerathan, R., Darr, S., Dougall, C., Ellis, R., Fentie, B., Hateley, L., 2017. Modelling pollutant load changes due to improved management practices in the Great Barrier Reef catchments: updated methodology and results, Technical Report for Reef Report Card 2014, Queensland Department of Natural Resources and Mines, Brisbane, Queensland.

McKenzie, L., Collier, C., Waycott, M., Unsworth, R., Yoshida, R., Smith, N., 2012. Monitoring inshore seagrasses of the GBR and responses to water quality.

McKenzie, L.J., Unsworth, R.K.F., Waycott, M., 2010. Reef Rescue Marine Monitoring Program: Intertidal Seagrass, Annual Report for the sampling period 1st September 2009 - 31st May 2010, Fisheries Queensland, Cairns.

Morgan, K.M., Perry, C.T., Johnson, J.A., Smithers, S.G., 2017. Nearshore Turbid-Zone Corals Exhibit High Bleaching Tolerance on the Great Barrier Reef Following the 2016 Ocean Warming Event. Frontiers in Marine Science 4.

Muir, P.R., Wallace, C.C., Done, T., Aguirre, J.D., 2015. Limited scope for latitudinal extension of reef corals. Science 348, 1135-1138.

Mumby, P.J., Chisholm, J.R., Edwards, A.J., Andrefouet, S., Jaubert, J., 2001. Cloudy weather may have saved Society Island reef corals during the 1998 ENSO event. Marine Ecology Progress Series 222, 209-216.

NASA Goddard Space Flight Center, Ocean Ecology Laboratory, Ocean Biology Processing Group, Moderate-resolution Imaging Spectroradiometer (MODIS) Aqua Ocean Color Data; 2018 Reprocessing, NASA OB.DAAC, Greenbelt, MD, USA. data/10.5067/AQUA/MODIS/L2/OC/2018. Accessed on 07/06/2020.

Neil, D.T., Orpin, A.R., Ridd, P.V., Yu, B., 2002. Sediment yield and impacts from river catchments to the Great Barrier Reef lagoon: a review. Marine and Freshwater Research 53, 733-752.

Noonan, S.H.C., DiPerna, S., Hoogenboom, M.O., Fabricius, K.E., (in prep). Effects of light variability and elevated CO2 on the adult and juvenile performance of two Acropora corals.

Orpin, A.R., Ridd, P.V., 2012. Exposure of inshore corals to suspended sediments due to wave-resuspension and river plumes in the central Great Barrier Reef: A reappraisal. Continental Shelf Research 47, 55-67.

Packett, R., Dougall, C., Rohde, K., Noble, R., 2009. Agricultural lands are hot-spots for annual runoff polluting the southern Great Barrier Reef lagoon. Marine pollution bulletin 58, 976-986.

Petus, C., da Silva, E.T., Devlin, M., Wenger, A.S., Álvarez-Romero, J.G., 2014. Using MODIS data for mapping of water types within river plumes in the Great Barrier Reef, Australia: Towards the production of river plume risk maps for reef and seagrass ecosystems. Journal of Environmental Management 137, 163-177.

Petus, C., Devlin, M., Teixera da Silva, E., Lewis, S., Waterhouse, J., Wenger, A., Bainbridge, Z., Tracey, D., 2018. Defining wet season water quality target concentrations for ecosystem conservation using empirical light attenuation models: A case study in the Great Barrier Reef (Australia). Journal of environmental management 213, 451-466.

Pitcher, R., Doherty, P., Arnold, P., Hooper, J., Gribble, N., Bartlett, C., Browne, M., Campbell, N., Cannard, T., Cappo, M., Carini, G., Chalmers, S., Cheers, S., Chetwynd, D., Colefax, A., Coles, R., Cook, S., Davie, P., De'ath, G., Devereux, D., Done, B., Donovan, T., Ehrke, B., Ellis, N., Ericson, G., Fellegara, I., Forcey, K., Furey, M., Gledhill, D., Good, N., Gordon, S., Haywood, M., Jacobsen, I., Johnson, J., Jones, M., Kinninmoth, S., Kistle, S., Last, P., Leite, A., Marks, S., McLeod, I., Oczkowicz, S., Rose, C., Seabright, D., Sheils, J., Sherlock, M., Skelton, P., Smith, D., Smith, G., Speare, P., Stowar, M., Strickland, C., Sutcliffe, P., Van der Geest, C., Venables, W., Walsh, C., Wassenberg, T., Welna, A., Yearsley, G., 2007. Seabed biodiversity on the continental shelf of the Great Barrier Reef World Heritage Area, AIMS/CSIRO/QM/QDPI CRC Reef Research Task Final Report., p. 315. 
Platt, T., Sathyendranath, S., White, G.N., III, Ravindran, P., 1994. Attenuation of visible light by phytoplankton in a vertically structured ocean: solutions and applications. Journal of Plankton Research 16, 1461-1487.

R Core Team, 2019. R: A language and environment for statistical computing. R Foundation for Statistical Computing, Vienna, Austria.

Ralph, P.J., Durako, M.J., Enríquez, S., Collier, C.J., Doblin, M.A., 2007. Impact of light limitation on seagrasses. Journal of Experimental Marine Biology and Ecology 350, 176-193.

Robillot, C., Logan, M., Baird, M., Waterhouse J., Martin, K., Schaffelke, B., 2018. Testing and implementation of an improved water quality index for the 2016 and 2017 Great Barrier Reef Report Cards: Summary Report, Report to the National Environmental Science Program., Reef and Rainforest Research Centre Limited, Cairns, p. 65.

Sakshaug, E., 1997. Parameters of photosynthesis: definitions, theory and interpretation of results. Journal of plankton research 19, 1637-1670.

Schaeffer, B., Hagy, J., Stumpf, R., 2013. Approach to developing numeric water quality criteria for coastal waters: transition from SeaWiFS to MODIS and MERIS satellites. APPRES 7, 073544.

Schaffelke, B., Carleton, J., Skuza, M., Zagorskis, I., Furnas, M.J., 2012. Water quality in the inshore Great Barrier Reef lagoon: Implications for long-term monitoring and management. Marine Pollution Bulletin 65, 249-260.

Skerratt, J.H., Mongin, M., Baird, M.E., Wild-Allen, K.A., Robson, B.J., Schaffelke, B., Davies, C.H., Richardson, A.J., Margvelashvili, N., Soja-Wozniak, M., Steven, A.D.L., 2019. Simulated nutrient and plankton dynamics in the Great Barrier Reef (2011-2016). Journal of Marine Systems 192, 51-74.

State of Queensland, 2018. Reef 2050 Water Quality Improvement Plan 2017-2022

Strahl, J., Rocker, M.M., Fabricius, K.E., 2019. Contrasting responses of the coral Acropora tenuis to moderate and strong light limitation in coastal waters. Marine Environmental Research 147, 80-89.

Sully, S., van Woesik, R., 2020. Turbid reefs moderate coral bleaching under climate-related temperature stress. Global Change Biology 26, 1367-1373.

Titlyanov, E.A., Latypov, Y.Y., 1991. Light-dependence in scleractinian distribution in the sublittoral zone of South China Sea Islands. Coral Reefs 10, 133-138.

Waterhouse, J., Lønborg, C., Logan M., Petus, C., Tracey, D., Lewis, S., Tonin, H., Skuza, M., da Silva, E., Carreira, C., Costello, P., Davidson, J., Gunn, K., Wright, M., Zagorskis, I., Brinkman R., Schaffelke, B., 2017. Marine Monitoring Program: Annual Report for inshore water quality monitoring 2015-2016. Report for the Great Barrier Reef Marine Park Authority, Great Barrier Reef Marine Park Authority, Townsville, p. 227.

Wells, S.C., Cole, S.J., Moore, R.J., Black, K.B., Khan, U., Hapuarachchi, P., Gamage, N., Hasan, M., MacDonald, A., Bari, M., Tuteja, N., 2017. Forecasting the water flows draining to the Great Barrier Reef using the G2G distributed hydrological model [Draft], Wallingford, UK.

Wolff, N.H., Mumby, P.J., Devlin, M., Anthony, K.R.N., 2018. Vulnerability of the Great Barrier Reef to climate change and local pressures. Global Change Biology 24, 1978-1991.

Yaakub, S.M., Chen, E., Bouma, T.J., Erftemeijer, P.L.A., Todd, P.A., 2014. Chronic light reduction reduces overall resilience to additional shading stress in the seagrass Halophila ovalis. Marine Pollution Bulletin 83, 467-474. 